Notre Dame Law School

NDLScholarship

Journal Articles

Publications

2017

\title{
Multiple Chancellors: Reforming the National Injunction
}

Samuel L. Bray

Notre Dame Law School, sbray@nd.edu

Follow this and additional works at: https://scholarship.law.nd.edu/law_faculty_scholarship

Part of the Constitutional Law Commons, Courts Commons, and the Judges Commons

\section{Recommended Citation}

Samuel L. Bray, Multiple Chancellors: Reforming the National Injunction, 131 Harv. L. Rev. 418 (2017).

Available at: https://scholarship.law.nd.edu/law_faculty_scholarship/1359

This Article is brought to you for free and open access by the Publications at NDLScholarship. It has been accepted for inclusion in Journal Articles by an authorized administrator of NDLScholarship. For more information, please contact lawdr@nd.edu. 


\title{
HARVARD LAW REVIEW
}

(c) 2017 by The Harvard Law Review Association

\author{
ARTICLES \\ MULTIPLE CHANCELLORS: \\ REFORMING THE NATIONAL INJUNCTION
}

\author{
Samuel L. Bray
}

\section{CONTENTS}

INTRODUCTION 418

I. THE ORIGINS OF THE NATIONAL INJUNCTION. . .424

A. The Absence of the National Injunction from Traditional Equity...........................425

B. The Changing Scope of Injunctions Against Federal Defendants ............................. 428

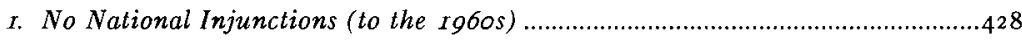

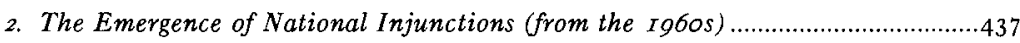

II. WHY DID THE NATIONAL INJUNCTION EMERGE? ...............................................445

A. The Structural Precondition: Multiple Chancellors....................................................446

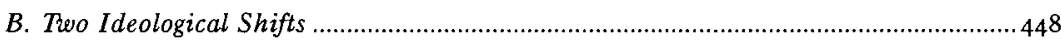

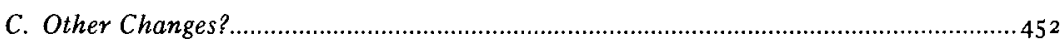

III. THE CONSEquences OF THE NATIONAI INJUNCTION …....................................457

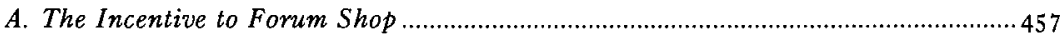

B. The Effect on Judicial Decisionmaking .....................................................................4 46

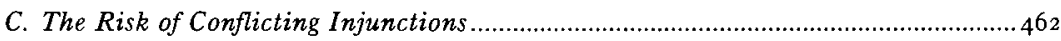

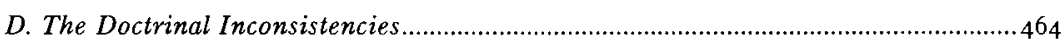

IV. The FaILURE OF EXISTING LIMITS ...................................................................465

V. WHERE SHOULD WE GO FROM HERE? ................................................................469

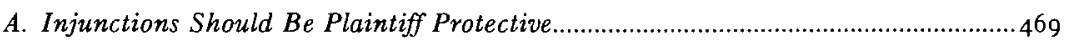

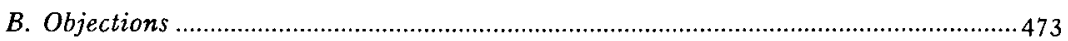

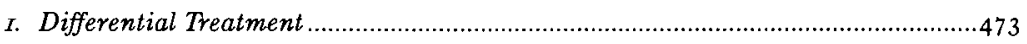

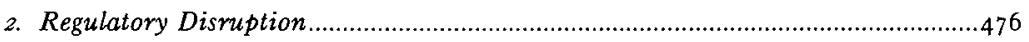

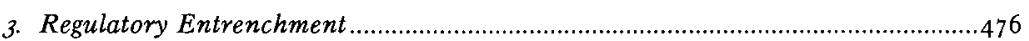

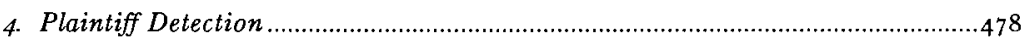

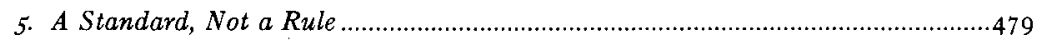

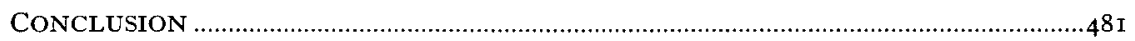




\title{
MULTIPLE CHANCELLORS: REFORMING THE NATIONAL INJUNCTION
}

\begin{abstract}
Samuel L. Bray*
In several recent high-profile cases, federal district judges have issued injunctions that apply across the nation, controlling the defendants' behavior with respect to nonparties. This Article analyzes the scope of injunctions to restrain the enforcement of a federal statute, regulation, or order. This analysis shows the consequences of the national injunction: more forum shopping, worse judicial decisionmaking, a risk of conflicting injunctions, and tension with other doctrines and practices of the federal courts.
\end{abstract}

This Article shows that the national injunction is a recent development in the history of equity. There was a structural shift at the Founding from a single-chancellor model to a multiple-chancellor model, but the vulnerabilities in the latter did not become visible until the mid-to late twentieth century, when there were changes in how judges thought about legal challenges and invalid laws. Only with those changes - only in the second half of the twentieth century - did the national injunction emerge.

This Article proposes a single clear rule for the scope of injunctions against federal defendants. A federal court should give what might be called a "plaintiff-protective injunction," enjoining the defendant's conduct only with respect to the plaintiff. No matter how important the question and no matter how important the value of uniformity, a federal court should not award a national injunction. This rule is based on equitable principles and on the scope of the "judicial Power" granted by the Constitution of the United States.

\section{INTRODUCTION}

$\mathrm{F}$ ederal district judges have taken to an odd practice: they are issuing injunctions that apply across the nation, controlling the defendant's behavior with respect to nonparties. A prominent example is the preliminary injunction in Texas v. United States, ${ }^{1}$ which shut down the implementation of the Obama Administration's most important immigration program. ${ }^{2}$ Another is the preliminary injunction in Washington

* Professor, UCLA School of Law. The writing of this Article was supported by a Harrington Faculty Fellowship at the University of Texas at Austin. For comments and criticisms on earlier drafts, I am grateful to William Baude, Josh Blackman, Bob Bone, Maureen Carroll, Nathan Chapman, Kevin Clermont, Kristen Eichensehr, Richard Fallon, Ranjit Hakim, Andy Hessick, Andrew Kull, Douglas Laycock, Marty Lederman, Michael Morley, Nicholas Parillo, Richard Re, Doug Rendleman, Bertrall Ross, Stephen E. Sachs, Eugene Volokh, Kevin Walsh, Patrick Wooley, Stephen Yeazell, and the participants in law faculty workshops at Notre Dame and the University of Texas at Austin. For helpful conversations and correspondence, I am grateful to Ronen Avraham, Aaron-Andrew Bruhl, Jud Campbell, Perry Dane, John Duffy, Ward Farnsworth, John Golden, Michael McConnell, Susan Morse, John Nagle, Andrew Pincus, Jeffrey Pojanowski, Zachary Price, Larry Sager, David Waddilove, Christopher Walker, and Howard Wasserman. I also thank Lei Zhang for his excellent research support and archival sleuthing.

1 Texas v. United States, 86 F. Supp. 3d 59 I (S.D. Tex.), aff'd, 809 F.3d I34 (5th Cir. 20I5), aff'd by an equally divided Court, $136 \mathrm{~S}$. Ct. $227 \mathrm{I}$ (2016) (mem.).

$2 I d$. 
$v$. Trump, ${ }^{3}$ which halted the implementation of President Trump's first executive order restricting entry by individuals from seven countries. ${ }^{4}$ How did this practice of issuing national injunctions begin? Is it defensible?

This Article offers a new analysis of the scope of injunctions to restrain the enforcement of a federal statute, regulation, or order. Without much controversy, federal courts have increasingly been acting as if they have the authority to issue "national injunctions." 5 That is, in non-class actions, federal courts are issuing injunctions that are universal in scope - injunctions that prohibit the enforcement of a federal statute, regulation, or order not only against the plaintiff, but also against anyone. There is a small but growing literature critical of the national injunction. ${ }^{6}$ The criticisms expressed in this literature are essentially correct, including that the national injunction encourages forum shopping and that it arrests the development of the law in the federal system. But there is a strange disconnect between the diagnosis and the cure. The solutions proposed in this literature rely heavily on existing principles and appeals to judicial self-restraint. If these solutions would work, they would already have worked.

3 Washington v. Trump, No. CI 7-OI4I, 2017 WL 462040 (W.D. Wash. Feb. 3, 20I 7 ) (granting temporary restraining order)

${ }_{4}$ See id. The challenged executive order was subsequently replaced. The second order was the subject of national injunctions, which were stayed in part by the Supreme Court, see Trump v. Int'l Refugee Assistance Project, I37 S. Ct. 2080, 2087-89 (2017) (per curiam), and later vacated and remanded with instructions to dismiss as moot, Trump v. Int'l Refugee Assistance Project, 20I 7 WL 4518553 (U.S. Oct. I0, 20I7) (mem.) (per curiam). The third order was also the subject of national injunctions. See Hawaii v. Trump, No. I 7-00050, 2017 WL 4639560 , at ${ }_{14}$ (D. Haw. Oct. I 7, 2017) (granting temporary restraining order), appeal docketed, No. 17-I7 68 (9th Cir. Oct. 24, 2017); Int'l Refugee Assistance Project v. Trump, No. I7-036I, 2017 WL 46743I4, at *40-4I (D. Md. Oct. $\mathrm{r}_{7}, 2017$ ). The litigation is continuing.

5 No term is perfect. "Nationwide injunction" is especially inapt, because it emphasizes territorial breadth, when the real point of distinction is that the injunction protects nonparties. See infra note I9. "Universal injunction" is better, though it does not include the distinctive fact that these injunctions constrain the national government, as opposed to state governments. See infra note 29 and accompanying text.

6 See Michael T. Morley, Nationwide Injunctions, Rule $23(B)(2)$, and the Remedial Powers of the Lower Courts, 97 B.U. L. REV. 6I5 (2017); Michael T. Morley, De Facto Class Actions? Plaintiff- and Defendant-Oriented Injunctions in Voting Rights, Election Lare, and Other Constitutional Cases, 39 HARV. J.L. \& PUB. POL'Y 487 (20I6) [hereinafter Morley, De Facto Class Actions?]; Zayn Siddique, Nationwide Injunctions, I 8 COLUM. L. REV. (forthcoming 20I8) (originally available as an online draft in 2016), https://ssrn.com/abstract=2801 387 [https://perma.cc/NXL8-KSDM]; Getzel Berger, Note, Nationwide Injunctions Against the Federal Government: A Structural Approach, $9_{2}^{2}$ N.Y.U. L. REV. I068 (20I 7); Daniel J. Walker, Note, Administrative Injunctions: Assessing the Propriety of Non-Class Collective Relief, go CORNELL L. REV. II I 9 (2005); see also Maureen Carroll, Aggregation for Me, but Not for Thee: The Rise of Common Claims in Non-Class Litigation, 36 CARDOZO L. REV. 201 7, 203034 (2OI5). Professor Douglas Laycock has questioned the use of injunctions that run beyond the plaintiffs. See DOUglas LAYCOCK, MODERN AMERICAN REMEDIES 275-76 (4th ed. 2010); Thomas C. Berg \& Douglas Laycock, Protecting Same-Sex Marriage and Religious Liberty, in RELIGION AND EQUALITY: LAW IN CONFLICT I67, I 72 n.25 (W. Cole Durham Jr. \& Donlu Thayer eds., 20I6). 
This Article shows how we got here, and where we should go. Its primary contributions, in other words, are two.

First, it offers a new understanding of the causes of the current problem. It shows that the national injunction is a recent development in the history of equity, traceable to the second half of the twentieth century. The older English and American practice was that an injunction would restrain the defendant's conduct vis-à-vis the plaintiff, not vis-àvis the world. ${ }^{7}$ Thus, judicial behavior about the scope of injunctions has changed. But more has changed than judicial behavior.

If the English Chancellor had given national injunctions, they would not have been particularly problematic. ${ }^{8}$ There would have been no forum shopping and no risk of conflicting injunctions issued to the same defendant. The reason is a structural feature of English equity: there was one Chancellor. ${ }^{9}$ By contrast, in the federal courts of the United States, every judge is a "Chancellor" in the sense of having power to issue equitable relief. The current problems from the national injunction are thus a result of two transformations. One involved judicial institutions (the number of Chancellors). That transformation was a necessary precondition for the second, which involved judicial behavior (the scope of relief granted). The multiple-chancellor model of the federal courts requires better behavior from judges about the scope of equitable relief, behavior we can no longer count on.

Second, this Article proposes a single clear rule for the scope of injunctions against federal defendants. A federal court should give a plaintiff-protective injunction, enjoining the defendant's conduct only with respect to the plaintiff. ${ }^{10}$ No matter how important the question and no matter how important the value of uniformity, a federal court should not award a national injunction. This rule, if adopted by the courts or by Congress, would alleviate the forum-shopping problem. It would restore the percolation of legal questions through different courts of appeals, allowing each circuit to reach its own conclusion pending resolution by the Supreme Court. And it would nearly eliminate the risk of directly conflicting injunctions.

\footnotetext{
7 The exceptions, including in rem suits, do not offer a basis for national injunctions. An injunction could control the defendant's conduct outside the court's territorial jurisdiction, but it would do so to protect the plaintiff, not to protect nonparties.

8 The injunction is an equitable remedy, developed primarily in the English Court of Chancery. For a sketch of the history of equity, see J.H. BAKER, AN INTRODUCTION TO ENGLISH LEGAL HISTORY 97-II6 (4th ed. 2002).

9 That is, Chancery was an essentially unitary institution. For further discussion and qualification of the point that there was one Chancellor, see infra section II.A, pp. 446-48.

10 A similar rule has been suggested by Laycock: "[T] globally prohibit a government agency from enforcing an invalid regulation; the court should order only that the invalid regulation not be enforced against the individual plaintiff." LAYCOCK, supra note 6 , at 276 .
} 
This rule is rooted in the authority of the federal courts. Article III gives the federal courts the "judicial Power," 11 which is a power to decide cases for parties, not questions for everyone. ${ }^{12}$ A further source of this rule is equitable principles. The federal courts are obligated to trace their equitable doctrines and remedies to the historic tradition of equity. ${ }^{13}$ In equity, however, injunctions did not control the defendant's behavior against nonparties. It is true that traditional equity lacked the sharply defined rule that is advanced here: because there was one Chancellor, Chancery never needed to develop rules to constrain the scope of injunctive relief. But translating traditional equity into the present, with sensitivity to the changed institutional setting, requires this rule.

The central objection to the proposal here is that it will lead to disuniformity in the law. That disuniformity will be of two kinds. First, if an injunction protects only the plaintiff, the federal government may continue to apply the invalidated statute, regulation, or order to other people. Second, once the disuniformity within a circuit is ended, usually but not always by a holding from the court of appeals, the federal government may continue enforcement in other circuits.

Is the bitter worth the sweet? Our system already tolerates a substantial amount of legal disuniformity. Without a decision by the Supreme Court, state courts and lower federal courts can reach different conclusions on the same question. ${ }^{14}$ The national government is not subject to offensive issue preclusion in later suits with different parties. ${ }^{15}$ When federal agencies lose in one circuit, they often continue litigating the question in other circuits. ${ }^{16}$

If this seems like madness, it has a method. If the circuits all agree, their precedents resolve the question; if they disagree, the Supreme Court gains from the clash of opposing views. We sacrifice immediate

11 U.S. CONST. art. III, $\S$ I.

12 See Ariz. Christian Sch. Tuition Org. v. Winn, 563 U.S. I 25, I32 (201 I); Lewis v. Casey, 518 U.S. 343,349 (r996).

13 See Grupo Mexicano de Desarrollo, S.A. v. All. Bond Fund, Inc., 527 U.S. 308, 3I8-29 (I999). Grupo Mexicano has been criticized. See, e.g., Stephen B. Burbank, The Bitter with the Sweet: Tradition, History, and Limitations on Federal Judicial Pover - A Case Study, 75 NOTRE DAME L. REV. I 29I (2000); Judith Resnik, Constricting Remedies: The Rehnquist Judiciary, Congress, and Federal Power, 78 IND. L.J. 223 (2003). Nevertheless, its emphasis on traditional equity has ample precedent, see John F. Duffy, Administrative Common Law in Judicial Review, 77 TEX. L. REV. II3, 126-30 (1998), and has been reiterated in subsequent cases, see Samuel L. Bray, The Supreme Court and the New Equity, 68 VAND. L. REV. 997 (2015).

14 See Arizonans for Official English v. Arizona, 520 U.S. 43, 58 n.II (I997); Lockhart v. Fretwell, 506 U.S. 364, 375-76 (I993) (Thomas, J., concurring) ("[N]either federal supremacy nor any other principle of federal law requires that a state court's interpretation of federal law give way to a (lower) federal court's interpretation." Id. at 376. .).

15 See United States v. Mendoza, 464 U.S. I 54, I 58-64 (I984).

16 See generally Samuel Estreicher \& Richard L. Revesz, Nonacquiescence by Federal Administrative Agencies, 98 YALE L.J. 679 (1989). 
resolution for what we hope will be better decisionmaking. ${ }^{17}$ The national injunction requires the opposite sacrifice, giving up deliberate decisionmaking for accelerated resolution. Cases still go to the Supreme Court, but without the benefit of decisions from multiple courts of appeals. If the national injunction issued by the district court is a preliminary one, the Supreme Court might even decide a major constitutional question on a motion for a stay. In that procedural posture, the Court would be reviewing lower court decisions reached in haste, and without the benefit of a record. Indeed, that very nearly occurred with the Take Care Clause claim in Texas v. United States, and with important questions about executive power and religious freedom in challenges to the immigration orders of President Trump. ${ }^{18}$ By returning to the older practice with respect to the scope of injunctions - the practice that obtained for more than a century and a half in the federal courts, and that is still followed in many cases - we choose patience and get better decisions. Measure twice, cut once.

The proposal made here differs sharply from the solutions proposed by most commentators. The limiting principles they have suggested include the physical boundaries of the court's jurisdiction, ${ }^{19}$ whether a broad injunction is necessary to provide "complete relief,"20 whether "the court believes the underlying right to be highly significant," 21 whether the challenge is to "a generally applicable policy or practice maintained by a defendant," 22 and whether "the challenged provision

17 But cf. Adrian Vermeule, Many-Minds Arguments in Legal Theory, I J. LEGAL ANALYSIS I (2009) (noting recurring problems with many-minds arguments).

18 On the possibility that the outcome of National Federation of Independent Business $v$. Sebelius, 567 U.S. 5 I9 (2012), would have been different if it had been decided on a motion to stay a preliminary injunction, see infra note 259.

19 See Morley, De Facto Class Actions?, supra note 6, at 535-38, 554; Berger, supra note 6, at I 100-04; see also Siddique, supra note 6 (manuscript at 6 ) (treating the relevant question as "the geographic scope of injunctions"). Such a solution has no basis in traditional equity. On the one hand, equity confined itself to controlling the defendant's behavior vis-à-vis the plaintiff. On the other hand, to protect the plaintiff, equity was willing to enjoin acts committed outside of the Chancellor's territorial jurisdiction. Equity acts in personam. Geographical lines are simply not the stopping point. See sources cited infra note 320 ; see also Ameron, Inc. v. U.S. Army Corps of Eng'rs, 787 F.2d 875, 888, 890-9I (3d Cir.), aff'd on reh'g, 809 F.2d 979 (3d Cir. 1986) (reversing injunction that controlled federal defendants' behavior within the District of New Jersey, in favor of an injunction controlling their behavior only against the plaintiff).

20 Siddique, supra note 6 (manuscript at $39-45$ ).

21 Zamecnik v. Indian Prairie Sch. Dist. No. 204, 636 F.3d 874, 879 ( 7 th Cir. 20I I) (Posner, J.) (quoting I DAN B. DOBBS, LAW OF REMEDIES $\S 2.4(6)$, at I I3 (2d ed. I993)). Zamecnik addressed the scope of an injunction, and though it did not involve a national injunction, it has been cited in support of national injunctions. See City of Chicago v. Sessions, No. I $7 \mathrm{C}_{5720,2017}$ WL 4572208 , at $*_{4-5}$ (N.D. Ill. Oct. I3, 2017 ).

22 PRINCIPLes of THE LAW OF Aggregate Litigation $\$ 2.04 \mathrm{cmt}$. a, at i i 7-I9 (AM. LAW INST. 20IO); see also Walker, supra note 6, at I I 4 I ("If a plaintiff successfully challenges a rule of 'broad applicability,' then the relief, the invalidation of the rule, will naturally extend to persons beyond the named plaintiffs."). 
can coherently be applied just to people other than the plaintiffs." 23 These approaches and proposals are all indeterminate. Some are question-begging, such as allowing national injunctions only against generally applicable policies. Some are even perverse, such as allowing national injunctions only in the most significant cases - a principle that would allow national injunctions only when the forum-shopping temptation is irresistible. They also tend to exhort judges to apply the existing principles in a restrained way. But if the rise of the national injunction was not due to willful judging - if it was latent in the structure of the federal courts and then manifested with changes in ideology ${ }^{24}$ then we must look elsewhere for the answer. Exhortation is not a solution to structural problems and ideological forces.

For the rule proposed here, the historical account of the origins of the national injunction is not mere background. The equitable doctrines and remedies of the federal courts must have a basis in traditional equity. ${ }^{25}$ The national injunction lacks the requisite basis. Moreover, this account exposes a complexity that scholars and courts need to consider when asking what is part of traditional equity. It is not enough to look at the past to see if some contemporary phenomenon can be spotted there, as if it were a beast in the wild. One must also consider the institutional setting - the one-chancellor setting — in which traditional equitable doctrines were fashioned. In that setting, certain powers and limits were developed. Other powers and limits were not developed, because there was no occasion for them. But we live in a multiplechancellor world. Given the gap between equity's past and present, sometimes a translation has to be made. ${ }^{26}$ Sometimes equity's principles have to change in order to stay the same.

In this Article, the assumption is that each case discussed is right on the merits; the analysis is about what the court's remedial response should have been. Without this assumption, the problem of national injunctions is intractable. It would be easy for a legal scholar, consciously or unconsciously, to think that a "sound" decision on the merits should be paired with a national injunction, while an "unsound" decision should be enforced with an injunction protecting only the plaintiff. But the injunction choice is made by the very same judge who decides the merits. The scope of the equitable remedy must be disentangled from the correctness of a particular merits decision.

\footnotetext{
23 Morley, De Facto Class Actions?, supra note 6, at 495-96.

24 Throughout this Article "ideological" is used to refer to intellectual shifts in thinking about law and the nature of the judicial role.

25 See supra note 13 and accompanying text.

26 See Samuel L. Bray, Form and Substance in the Fusion of Lare and Equity, in EQUITY AND LAW: FUSION AND FISSION (John Goldberg, Henry Smith \& Peter Turner eds., forthcoming 20r8).
} 
This analysis considers injunctions that federal courts issue against federal defendants. This inquiry has complications enough without considering other kinds of cases. Even so, the analysis can apply more broadly. First, in suits between private parties, it is already the case that the practice of the federal courts is generally aligned with the suggestions in this Article. ${ }^{27}$ Second, the rule advanced here would logically apply whenever federal courts enjoin state defendants. ${ }^{28}$ That is, federal courts should issue injunctions that control a state defendant's conduct vis-à-vis the plaintiff, not vis-à-vis nonparties. ${ }^{29}$ Finally, the analysis here could be extended to injunctions issued by state courts. Whether it should be, however, depends on a state's preference either for speedy resolution of legal questions or for an accumulation of multiple judicial opinions (in hope of epistemic advantages).

The argument proceeds as follows. Part I describes the origins of the national injunction, showing its absence from traditional equity and its emergence in the second half of the twentieth century. Part II considers the question of what changed. It highlights two shifts in how judges viewed challenges to invalid laws. Part III describes the consequences of the national injunction: forum shopping, worse decisionmaking, a risk of conflicting injunctions, and tension with other doctrines and practices of the federal courts. Part IV shows the failure of what, in existing law, is the primary constraint on national injunctions, namely, the "complete relief" principle. Finally, Part V proposes a simple rule: federal courts should issue injunctions that control a federal defendant's conduct only with respect to the plaintiff. If adopted, this rule will keep one Chancellor's foot from stepping on another Chancellor's toes.

\section{THE ORIGINS OF THE NATIONAL INJUNCTION}

Whenever the court's holding is that a federal statute, regulation, or order is unlawful, the court must decide the scope of the remedy. One

27 For example, when one company is enjoined from using another's patent, even though the territorial scope of the injunction may be universal, the injunction does not prohibit the defendant from infringing the patents of other patent holders. Rather, it protects only the plaintiff, and only against an almost exact repetition of the previous infringement. See John M. Golden, Injunctions as More (or Less) Than "Off Switches": Patent-Infringement Injunctions' Scope, go TEX. L. REV. I399 (20I2). There are exceptions, such as some Title VII suits.

28 Municipalities have long been subject to broader equitable relief. See infra notes $68-69$ and accompanying text.

29 There are pragmatic reasons for distinguishing federal defendants from state defendants. Because a state government is within only one federal court of appeals, plaintiffs suing state defendants have less incentive to forum shop. (It may also be easier to engage in forum shopping against federal defendants because of broad venue rules.) For the same reason, there is less risk of conflicting injunctions from different courts. The fact that a state government is within only one federal court of appeals also makes it somewhat less likely that a federal circuit split will develop about the meaning of a state law. 
of the available remedies is the injunction, which requires the defendant to do or refrain from doing some act. The injunction is a "national injunction" when it controls the federal defendant's conduct against everyone, not just against the plaintiff.

The equitable doctrines and remedies of the federal courts must find some warrant in the traditional practice of equity, especially as it existed in the Court of Chancery in $1789 .{ }^{30}$ This Part shows the absence of the national injunction from traditional equity, and locates the origin of the national injunction in the second half of the twentieth century.

\section{A. The Absence of the National Injunction from Traditional Equity}

There is an easy, uncomplicated answer to the question whether the national injunction is traceable to traditional equity: $n o$.

In English equity before the Founding of the United States, there were no injunctions against the Crown. No doubt part of the explanation was the identification of the Chancellor with the King, an identification that was important in the early development and selfunderstanding of the Court of Chancery. ${ }^{31}$ Without injunctions against the Crown, it would be easy to see why there were no broad injunctions against the enforcement of statutes. ${ }^{32}$ There were sometimes suits to restrain the actions of particular officers against particular plaintiffs. ${ }^{33}$ And the Attorney General could be a defendant in Chancery in certain kinds of cases "in which the interests of the Crown" were not "immediately concerned." 34 Still, there was nothing remotely like a national injunction.

Equity would sometimes resolve a number of claims at once. To get into equity, a plaintiff needed to show that his case fit under one of the heads of equitable jurisdiction. One of these, "multiplicity of suits," could be invoked when the equity plaintiff wanted to avoid repeated

\footnotetext{
30 See, e.g., Grupo Mexicano de Desarrollo S.A. v. All. Bond Fund, Inc., 527 U.S. 308, 3 I $8-19$ (1999).

31 J.D. Heydon, M.J. Leeming \& P.G. TuRner, Meagher, Gummow \& LeHane's EQUITY: DOCTRINES AND REMEDIES $\$ 2 \mathrm{I}-510$, at 787 (5th ed. 2015) ("Under the general law the Court of Chancery had no jurisdiction to issue injunctions against the Crown, since the court was itself an emanation of the Crown.").

$32 C f$. LOUIS L. JAFFe, JUdiCIAL CONTROL OF AdMINISTRATIVE ACTION 466 \& n.3 I (i 965) ("English history is sparse and obscure with respect to bills in equity by taxpayer or citizen." Id. at 466.). A similar point could be made about the prerogative writs. See id. at 462 ("The prerogative writs, in their origin and until the middle of the Nineteenth Century, were used primarily to control authorities below the level of the central government. The King and his ministers were controlled, if at all, by Parliament.").

33 HEYDON, LEEMING \& TURNER, supra note $3 \mathrm{I}, \S 2 \mathrm{I}-5 \mathrm{IO}$, at 787

34 I Edmund Robert DANIEll, THE PRACTICE of THE High Court of Chancery I 38 (London, V. \& R. Stevens \& G.S. Norton, 2d ed. I845) (emphasis omitted). For discussion, see id. at $138-47$.
} 
instances of litigation with the same opposing party (for example, repeated trespass). ${ }^{35}$

In addition, to avoid a multiplicity of suits, equity would give a "bill of peace."36 With this device, the Chancellor would consolidate a number of suits that would not be sequential between two parties. These might be suits involving some kind of common claim the plaintiff could have against multiple defendants (for example, a lord suing all of his tenants, or a vicar suing all of his parishioners). Or these might be suits involving some kind of common claim that multiple plaintiffs could have against a single defendant (for example, the tenants suing the lord, or the parishioners suing the vicar). ${ }^{37}$

A bill of peace with multiple plaintiffs who represented the whole set of possible plaintiffs - some tenants representing all of the tenants, or some parishioners representing all of the parishioners - is probably the closest analogy in traditional equity to the national injunction. The analogy is not close. A bill of peace was not used to resolve a question of legal interpretation for the entire realm. It was not enough that many people were interested in or affected by the outcome. It was instead a kind of proto-class action. The group was small and cohesive; in present terms, we might say its interest was common. One could think of the Chancellor as hearing the plaintiffs' claim, which was identical to the claims of others within a preexisting social group, and then rounding up the scope of the decision (from most tenants to all tenants, for example). ${ }^{38}$ The Chancellor would then control the defendant's conduct with respect to this rounded-up group of plaintiffs and nonplaintiffs. The Chancellor would not control the defendant's conduct against the world, or against other potential plaintiffs who might bring other kinds of claims.

35 Henry L. MCClintock, HANDBook of the PRINCIPLES OF EQUity 480-82 (2d ed. I948).

36 See I JOHN NORTON POMEROY, A TREATISE ON EQUiTy JURISPRUDENCE $\$ \$ 245-246$, at 464-68 (Spencer W. Symons ed., 5th ed. T94 I).

37 Chancery suits involving these different uses of a bill of peace are cited in 2 JAMES BARR AMEs, A SELECTION OF CASES IN EquiTy JURISDiCTION 55 (I 29 g). For sketches of two of the classic cases, How v. Tenants of Bromsgrove and Brown v. Vermuden, see Stephen C. Yeazell, Group Litigation and Social Context: Toward a History of the Class Action, 77 COLUM. L. REv. 866, 869-7 I ( 1977 ). Many of these representative suits were "impersonal." See Robert G. Bone, Personal and Impersonal Litigative Forms: Reconceiving the History of Adjudicative Representation, 7o B.U. L. REV. $21_{3}$ (I990) (reviewing STEPHEN C. YeaZelL, From Medieval Group LitiGATION TO THE MODERN CLASS ACTION (I987)).

38 See Geoffrey C. Hazard, Jr., John L. Gedid \& Stephen Sowle, An Historical Analysis of the Binding Effect of Class Suits, I46 U. PA. L. REV. 1849, I865 (1998) (describing early English bill of peace cases as ones in which "the court could treat groups - fellow tenants, fellow miners, fellow merchants - as some kind of set or entity for procedural purposes"); Yeazell, supra note 37, at 8707 I (noting, for "the earliest group litigation for which we have published reports," id. at 870 , that all the cases "involve[d] disputes arising out of manor or parish communities," id. at $87 \mathrm{I}$ ). 
These principles were carried over into American equity. ${ }^{39}$ A suit had to fall under one of the recognized heads of equity jurisprudence. ${ }^{40}$ Courts would "take care to make no decree [that would] affect" the rights of nonparties. ${ }^{41}$ As for the bill of peace, one application and extension came in suits by taxpayers against tax collectors. Beginning in the mid-nineteenth century, some state courts were willing to enjoin the collection of an illegal tax, not only with respect to the plaintiffs but with respect to any taxpayer; other state courts disagreed, and would give relief only as to the plaintiffs. ${ }^{42}$ Yet when courts did give broader relief it was in cases involving municipal or county taxes. ${ }^{43}$ The theory was still that the bill of peace, or the injunction in the nature of a bill of peace, was resolving the common claims of a cohesive group, what might be called a micropolity. ${ }^{44}$

There is evidence that late in the nineteenth century courts extended this reasoning from suits to enjoin tax collection to other challenges, allowing a successful plaintiff to obtain an injunction protecting all similarly situated persons. Again what was challenged were not federal or state laws but municipal ordinances. ${ }^{45}$

39 See Smith v. Swormstedt, 57 U.S. (I6 How.) 288, 302-03 (I854); 2 JOSEPH STORY, COMMENTARIES ON EqUiTY JURISPRUDENCE $\$ \$ 854-857$, at I $90-93$ (Boston, Charles C. Little \& James Brown, 4th ed. 1846 ). One treatise writer noted with disapproval that the American courts were "reluctant to go much beyond" the English decisions in which the Chancellor granted a bill of peace. GEORGE L. CLARK, PRINCIPLES OF EQUITY $\$ 439$, at 580 (I937).

40 E.g., Dows v. City of Chicago, 78 U.S. (II Wall.) 108, I09-Io (I 870 ).

41 Joy v. Wirtz, I3 F. Cas. II 72 , I I 74 (C.C.D. Pa. I806) (No. 7554) (Washington, J.) (creditors' bill); see also 3 ThOMAs W. WATERMAN, THE AMERICAN CHANCERY DIGEST 157 (New York, Banks, Gould \& Co., 3d ed. I85 I) ("Care will be taken not to make a decree which will affect the person who is not a party to the suit." (citing Joy, I3 F. Cas. I1 72 )).

42 See CLARK, supra note $39, \$ 443$, at $589-9 \mathrm{I}$.

43 E.g., Carlton v. Newman, I A. I94 (Me. I885) (municipal tax); McTwiggan v. Hunter, 30 A. 962, 963 (R.I. I 895) (municipal tax). See generally I POMEROY, supra note $36, \$ 260$, at 526-37.

$44 \mathrm{Cf}$. Smith, 57 U.S. at 303 ("[A] court of equity permits a portion of the parties in interest to represent the entire body...." (emphasis added)); I POMEROY, supra note $36, \S 260$, at 534 ("[C]omplete and final relief may be given to an entire community by means of one judicial decree...:" (emphasis added)). Note that a related question is the ability of a taxpayer to get an injunction restraining not the illegal collection of money but its illegal expenditure. That kind of suit, which is usually called a "taxpayer's suit," also seems to be traceable to the mid-nineteenth century in municipal cases. See Crampton v. Zabriskie, IoI U.S. 60I, 609 (I880); JAFFE, supra note 32 , at $470-7 \mathrm{I}$. Courts were slower to allow suits enjoining the collection of a state tax with respect to nonplaintiffs. That development was almost entirely confined to the twentieth century, and as late as I 960 there were many states that either did not allow taxpayer suits (for example, New York), or had not resolved the question (for example, California). See id.; Note, Taxpayers' Suits: A Survey and Summary, 69 YALE L.J. 895, go: \& nn.3 I \& 33 (Ig60).

45 See, e.g., City of Chicago v. Collins, 5 I N.E. 907, 908, 9I I (Ill. I898). See generally I AMERICAN AND ENGLISH DECISIONS IN EQUITY $75-77$ (Henry Budd ed., Philadelphia, M. Murphy I895); I POMEROY, supra note $36, \S 26 \mathrm{Ib}$, at 540-4I; Note, Equity - Jurisdiction - Prevention of Multiplicity of Suits, I6 MINN. L. REV. 679 (I932). Professor Bob Bone has said of the late nineteenth- and early twentieth-century courts: "[T]he importance of conclusively establishing the legality of official acts as well as the desirability of preventing burdensome repetitive litigation were 


\section{B. The Changing Scope of Injunctions Against Federal Defendants}

There were apparently no national injunctions against federal defendants for the first century and a half of the United States. They seem to have been rejected as unthinkable as late as Frothingham v. Mellon, ${ }^{46}$ and to have been conspicuously absent as late as Youngstown Sheet \& Tube Co. v. Sawyer. ${ }^{47}$ They did not remain so. The I96os and I97os were a time of flux in regard to the scope of injunctions - national injunctions seemed to be within the power of a federal district court, but there was some uncertainty or discomfort about using them. By the I 980 a and I990s, to some judges they were an ordinary part of the remedial arsenal of the federal courts. There was no major case. No statute altered the federal courts' powers. Instead, the changes seem to have been gradual and driven by shifts in thinking about preventive suits and invalid laws.

I. No National Injunctions (to the Ig6os). - In the nineteenth century, federal courts would issue injunctions that protected the plaintiff from the enforcement of a federal statute, regulation, or order - not injunctions that protected all possible plaintiffs throughout the United States. ${ }^{48}$ For example, in Georgia v. Atkins, ${ }^{49}$ the state of Georgia sued in federal court for an injunction against James Atkins, a federal tax collector. Georgia's claim was that it was illegal to impose a federal corporate tax upon a state (in this case, a tax on the Western \& Atlantic Railroad that was owned and operated by the state of Georgia). The court agreed and issued an injunction. But the injunction was not against the enforcement of the tax upon states generally, nor even against the enforcement of the tax upon Georgia generally, but rather to

strong affirmative reasons to bar subsequent suits by nonparty class members, whether the plaintiff won or lost her first suit." Bone, supra note 37 , at 275 . Bone's conclusion does not appear to contradict the point made here: the support he cites is a federal equity case from I $90 \mathrm{I}$ involving a challenge to a municipal ordinance. Id. at $275 \mathrm{n}$. I5 I (citing McIntosh v. City of Pittsburg, I $22 \mathrm{~F}$. 705, 709 (C.C.W.D. Pa. I90I)).

46 Massachusetts v. Mellon (Frothingham), 262 U.S. 447 (I923).

47343 U.S. 579 (1952).

48 Note that before 1875 the federal courts lacked statutory federal question jurisdiction, apart from a brief period from I 801 to I 802 . See Judiciary Act of 1801 , ch. 4, $\$$ I I, 2 Stat. 89, 92 (repealed I 802 ) (establishing federal question jurisdiction); Judiciary Act of I 875 , ch. I $37, \S$ I, I 8 Stat. 470 , 470 (codified as amended at 28 U.S.C. $\$$ I 33 I (2OI2)) (reestablishing federal question jurisdiction). Yet, even without federal question jurisdiction, the federal courts would still have had the opportunity - where sovereign immunity could be avoided - to restrain the enforcement of a federal statute, regulation, or order in the following circumstances: (a) an injunction issued by the U.S. Supreme Court in its original jurisdiction; (b) an injunction in a diversity suit, including one brought by an alien, that somehow managed to include a federal officer or agency; (c) a suit by the United States; (d) a suit in admiralty; (e) a suit by a federally chartered corporation, such as the Bank of the United States; and (f) a suit by a state. I am grateful to Professors Will Baude and Stephen Sachs for discussion of this list.

49 Io F. Cas. 24I (C.C.N.D. Ga. I 866) (No. 5350) (bill in equity). This is an example of category (f) in the preceding footnote. 
restrain Mr. Atkins "from further proceeding in the collection of the sum of six thousand and four dollars and fifty-six cents, claimed to be due to the United States."50 The scope of the injunction matched what the court perceived as the scope of its authority. That is, the court recognized its "jurisdiction or power ...., if the tax sought to be collected is illegal, unwarranted by the act of congress, to interpose by writ of injunction, and arrest the threatened invasion of the property of the complainant." 1

In fact, in the nineteenth century, the idea of suing to restrain the enforcement of a federal statute everywhere in the nation seems not to have found any acceptance, and it may never even have been raised. Consider, by comparison, a suit against a state. In 1895 , James Donald sued the state of South Carolina, arguing that the confiscation of alcohol that he imported for his own private consumption was a violation of the federal Constitution. ${ }^{52}$ The U.S. Supreme Court held the state statute unconstitutional. ${ }^{53} \mathrm{Mr}$. Donald asked for damages, ${ }^{54}$ as well as an injunction restraining the enforcement of the statute by any state executive officer against Mr. Donald or anyone else. ${ }^{55}$ The Court objected to the overbroad injunction, ${ }^{56}$ and its reasoning would apply a fortiori to a national injunction:

But while we think that the complainant was entitled to an injunction against those defendants who had despoiled him of his property, and who were threatening to continue so to do, we are unable to wholly approve the decree entered in this case.

The theory of the decree is that the plaintiff is one of a class of persons whose rights are infringed and threatened, and that he so represents such class that he may pray an injunction on behalf of all persons that constitute it. It is, indeed, possible that there may be others in like case with the plaintiff, and that such persons may be numerous, but such a state of facts is too conjectural to furnish a safe basis upon which a court of equity ought to grant an injunction. ${ }^{57}$

$50 \mathrm{Id}$. at $24 \mathrm{I}$.

51 Id. at 242 (emphasis added).

52 See Scott v. Donald, I65 U.S. 58, 59, 78-86 (I 897) (law side).

53 See id. at 99-IOI.

54 Id. at 59 .

55 Scott v. Donald, I65 U.S. I07, I Io (1897) (equity side).

56 On this point the Court was seemingly unanimous. Justice Brown dissented without an opinion. Id. at II 7. But because he dissented with an opinion in the counterpart case on the Court's law side, which resolved Mr. Donald's challenge to the constitutionality of the statute, it seems almost certain that his dissent had more to do with the merits than with the remedy - he would not have wanted an even broader injunction. See Scott, I65 U.S. at I02-07 (Brown, J., dissenting). Justice Brewer did not participate in the resolution of the case.

57 Scott, I65 U.S. at II 5. 
Beginning in I906, Congress gave the federal courts power to review the orders of the Interstate Commerce Commission (ICC). ${ }^{58}$ The grant of jurisdiction was needed "because then, for the first time, the ratemaking power was conferred upon the commission, and then disobedience of its orders was first made punishable." 59 When shippers challenged these ratemaking orders from the ICC in federal court, and succeeded, the injunction would be limited in scope to the parties. For example, the ICC's order setting the shipping rate at $x$ for this shipper was invalid and its enforcement enjoined. 60

Or consider another case, one in which a federal agency rule was challenged on the grounds that it exceeded the agency's jurisdiction. In Waite v. Macy, ${ }^{61}$ tea importers sought to enjoin the federal Tea Board from applying to their teas a regulation blocking the import of any tea containing artificial coloring. ${ }^{62}$ The Court held the regulation invalid, because it exceeded the statute that gave the Tea Board its authority, but the Court upheld an injunction that apparently protected only the plaintiffs. ${ }^{63}$

A case worth considering in detail is Frothingham v. Mellon. It is now generally considered to be a case about "taxpayer standing," 64 but that is not how it was decided by the Supreme Court. The case looks quite different when seen through the lens of equity. The individual plaintiff, Harriet Frothingham, brought a suit to enjoin various federal officers from spending money under the authority of the Maternity Act, on the ground that the statute exceeded the power of the national government. ${ }^{65}$ The complaint demanded a national injunction. ${ }^{66}$ Indeed,

58 2 F. TROWBRDGE VOM BAUR, FEDERAL ADMINISTRATIVE LAW $\$ 635$, at 616 (I942) (referring to the Hepburn Act of I906, ch. 359I, $\S 5,34$ Stat. 584, 590, 592 (codified as amended in scattered sections of 49 U.S.C.)).

59 Id.

60 "Even when a large shipper secured an injunction, the scope of its relief often protected only that particular shipper, leaving his weaker competitors at the mercy of the new rate." Arrow Transp. Co. v. S. Ry. Co., 372 U.S. $658,663-64\left(\mathrm{r}_{9} 6_{3}\right)$. The power to enjoin ICC ratemaking orders was also constrained by the requirement of a three-judge court and a direct appeal as of right to the Supreme Court. 2 VOM BAUR, supra note $58, \$ 634$, at $615-16$.

61246 U.S. 606 (I9I8).

62 Id. at $607-09$. A coincidence, it seems, but the coloring at issue in this 19 I 8 case was "Prussian Blue." Id. at 608 .

63 See id. at 607 ("This is a bill brought by importers of tea to prevent the appellants, a board of general appraisers known as the Tea Board, from applying to tea imported by the plaintiffs tests which, it is alleged, are illegal and if applied will lead to the exclusion of the tea." (emphasis added)); id. at $609-10$.

64 See, e.g., Elizabeth Magill, Standing for the Public: A Lost History, 95 VA. L. REV. I I3 I, II69 (2009) (referring to "the prohibition on taxpayer standing established in 1923 in Frothingham $v$. Mellon").

65 Frothingham, 262 U.S. $447,448,479$ (1923).

66 Transcript of Record at 6-7, Frothingham, 262 U.S. 447 (No. 962) ("Wherefore the plaintiff prays that said Sheppard-Towner Act be declared unconstitutional and void, and that the Defendants their assistants, agents and servants be enjoined and restrained from acting or proceeding 
if Mrs. Frothingham were to have any remedy, it would have to be a national injunction: a prohibition on using her tax money for the $\mathrm{Ma}$ ternity Act would have been wholly ineffectual, because of the fungibility of money. The federal trial court, which was then called the Supreme Court of the District of Columbia, denied the injunction, and the court of appeals affirmed pro forma. ${ }^{67}$ In an opinion for a unanimous Supreme Court of the United States, Justice Sutherland made three arguments for why Mrs. Frothingham could not receive an injunction.

First, the Court distinguished the cases allowing one person to sue on behalf of others. The Court noted that individual taxpayers could sue municipal corporations (such as a city), and that the relationship of the individual to a municipal corporation resembled the relationship of a stockholder to a private corporation. ${ }^{68}$ For a reader steeped in the bill-of-peace precedents from English and American equity, Justice Sutherland was making a point about equitable jurisdiction. Equity allowed certain kinds of representative suits, and in nineteenth-century American law the prototypical examples were suits against municipal corporations and public corporations by one or more individual plaintiffs (taxpayers and stockholders, respectively). ${ }^{69}$ But the scale and relationship of the individual to the national government were "very different." In a case like this, Justice Sutherland wrote, "no basis is afforded for an appeal to the preventive powers of a court of equity."71

under the alleged authority of said Act to carry its provisions into effect, or to expend the public monies for that purpose, and that the Plaintiff may have such other and further relief as to this Court may seem just and equitable.").

67 Id. at I I-I2. This was done to speed the case to the U.S. Supreme Court, so it could be paired with a case in the Court's original jurisdiction. Id.

68 Frothingham, 262 U.S. at $486-87$.

69 E.g., Hill v. Wallace, 259 U.S. 44 (1922) (allowing eight members of the Chicago Board of Trade to sue the Secretary of Agriculture on behalf of all 16 Io members, seeking an injunction that would restrain the enforcement against the Board of an allegedly unconstitutional statute); see Hazard, Gedid \& Sowle, supra note 38, at $1889-90$ (noting analogy in nineteenth century between taxpayer suits and stockholder suits); see also id. at $185_{2}$ (noting the strong legal emphasis on the "unitary aspect" of corporations, "whether business, nonprofit, or municipal"). The conditions under which equity would intervene were reminiscent of the business judgment rule:

No principle of equity jurisprudence is, perhaps, better established than that when the officers of a municipal corporation are clothed with a discretionary power, and are acting within the scope of such power, a court of equity will not sit in review of their proceedings, or interfere by injunction, at the suit of a private citizen, unless fraud is shown, or the power of discretion is being manifestly abused, to the oppression of the citizen.

I AMERICAN AND ENGLISH DECISIONS IN EQUITY, supra note 45 , at 73-74. The resemblance is especially striking if the business judgment rule is seen as an abstention doctrine. See Stephen M. Bainbridge, The Business Judgment Rule as Abstention Doctrine, 57 VAND. L. REV. 83 (2004).

70 Frothingham, 262 U.S. at 487.

71 Id. The Court also described the relationship of the municipal taxpayer to the corporation in terms of "reasons which support the extension of the equitable remedy." Id. For a more critical view of the Court's unwillingness to extend the municipal cases to the national government, see Richard A. Epstein, Standing and Spending - The Role of Legal and Equitable Principles, 4 CHAP. L. REV. I, 34-35 (200I). 
Second, the Court invoked logistical problems - "inconveniences" 72 - that would be caused by letting individual taxpayers bring suits like Mrs. Frothingham's:

If one taxpayer may champion and litigate such a cause, then every other taxpayer may do the same, not only in respect of the statute here under review but also in respect of every other appropriation act and statute whose administration requires the outlay of public money, and whose validity may be questioned. ${ }^{73}$

Here the Court emphasized that "no precedent sustaining the right to maintain suits like this has been called to our attention." 74

Finally, the Frothingham Court suggested that the plaintiffs had fundamentally misunderstood our constitutional system and the role of the federal courts. The Court carefully distinguished suits to require executive officers to perform ministerial duties. ${ }^{75}$ Then the Court rebuked the very notion that it could give relief, in words that had nothing to do with the fact that Mrs. Frothingham was a taxpayer and everything to do with the fact that she sought a national injunction. The federal courts could hear a suit to prevent an enforcement action, but they could not decide a freestanding challenge to a statute. ${ }^{76}$ What they can do with respect to an invalid statute "amounts to little more than the negative power to disregard an unconstitutional enactment." 7 The Court then proceeded to what it saw as the fundamental problem with the suit, a question now considered in terms of "standing" but one that for the Court involved not only standing but also the kind of remedy equity could afford:

The party who invokes the power must be able to show not only that the statute is invalid but that he has sustained or is immediately in danger of sustaining some direct injury as the result of its enforcement, and not merely that he suffers in some indefinite way in common with people generally. If a case for preventive relief be presented the court enjoins, in effect, not the execution of the statute, but the acts of the official, the statute notwithstanding. Here the parties plaintiff have no such case. Looking through forms of words to the substance of their complaint, it is merely that officials of the executive department of the government are executing and will execute an

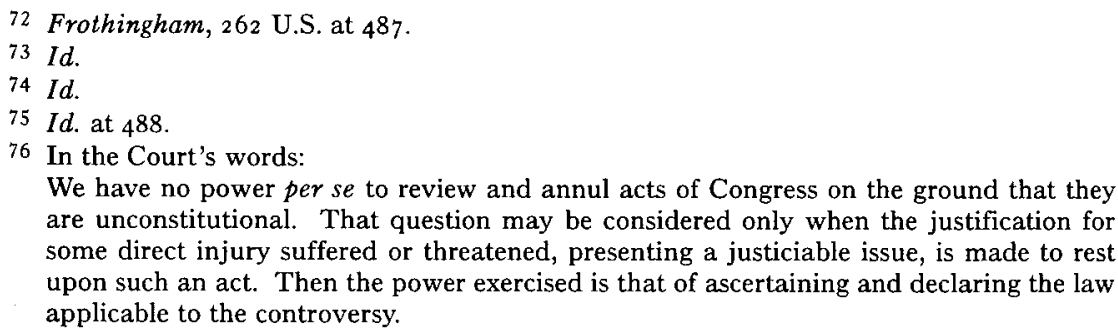
are unconstitutional. That question may be considered only when the justification for some direct injury suffered or threatened, presenting a justiciable issue, is made to rest upon such an act. Then the power exercised is that of ascertaining and declaring the law applicable to the controversy. 
act of Congress asserted to be unconstitutional; and this we are asked to prevent. To do so would be not to decide a judicial controversy, but to assume a position of authority over the governmental acts of another and co-equal department, an authority which plainly we do not possess. ${ }^{78}$

In short, to call Frothingham a case about "standing" misunderstands the way its analysis intertwines concepts of equity, remedies, and the judicial power. The Court was being asked to "prevent" (that is, enjoin) the enforcement of the statute, not just against a plaintiff who was threatened with direct injury, but against "people generally." And that, the Court concluded, was beyond the powers conferred by Article III.

More examples of the traditional pattern can be given. In Adkins $v$. Children's Hospital of the District of Columbia, ${ }^{79}$ a challenge was brought to a federal statute establishing a minimum wage for women in the District of Columbia. The plaintiffs, including a hospital, received an injunction that prohibited the enforcement of the law only against themselves. ${ }^{80}$

In Panama Refining Co. $v$. Ryan, ${ }^{81}$ the plaintiffs challenged a statutory provision allowing the President to restrict interstate shipment of oil, as well as regulations promulgated by the Department of the Interior under the statutory provision. ${ }^{82}$ The provision was part of the National Industrial Recovery Act, a central piece of New Deal legislation. It was exactly the kind of case that today would feature a request for a national injunction. But the plaintiffs did not seek one. Instead they sought an injunction against three federal officers - all then residing in Texas to keep them from enforcing the law against the plaintiffs. ${ }^{83}$ In particular, they sought an injunction that would keep "the defendants from further coming upon the refining plant of the plaintiff, Panama Refining Company, or interfering with it in any manner" in its refining, purchasing, and disposing of oil; restrain the defendants "from coming upon the property of the plaintiff, A. F. Anding"; prohibit them "from further demanding of either of the plaintiffs reports called for" in regulations promulgated under the Act; and restrain them "from instituting any criminal proceedings against these plaintiffs because of the violation" of the regulations. ${ }^{84}$ The district court proceeded to enjoin the defendants "from enforcing any rule or regulation ... under the National Industrial

78 Id. at $488-89$.

7926 I U.S. 525 ( 1923$)$.

80 Transcript of Record at I5, Adkins (No. 795).

81293 U.S. 388 (I935).

82 Id. at $405-\mathrm{I}$ I.

83 Transcript of Record at I-2, Panama Refining Co. (No. 135). One of these officers, J. Howard Marshall, was an assistant to the Attorney General of the United States "temporarily residing in Smith County, Texas" in I933. Id. at I. Sixty-one years later he gained a measure of notoriety from marrying Anna Nicole Smith.

84 Id. at 8-9. 
Recovery Act insofar as the same applies to ... petroleum," 85 and from "going upon or about the premises of complainants or in any wise interfering with them." ${ }^{86}$ To a reader today, the first part of the injunction quoted might seem to reach beyond the parties. But there is no evidence it was understood that way at the time, and there is considerable evidence that everyone recognized that the district court gave the plaintiffs what they sought: a plaintiff-protective injunction. ${ }^{87}$

Indeed, the litigation resulting in Panama Refining Co. v. Ryan was only part of a larger wave of challenges to New Deal legislation. As then-Attorney General Robert Jackson described it, after the Supreme Court held various New Deal acts unconstitutional, "'hell broke loose' in the lower courts." ${ }^{88}$ The precise form that hell took was the grant of "injunctions restraining officers of the Federal Government from carrying out acts of Congress." 89 How many injunctions were there? Against the enforcement of just one statutory provision, the processing tax in the Agricultural Adjustment Act, there were I600 injunctions. ${ }^{90}$ The Department of Justice released a report in 1937 called Injunctions in Cases Involving Acts of Congress, which reviewed and tabulated all of these injunctions with an eye toward their effect on the national government.91 I have not reviewed these thousands of decrees, but the report itself makes no mention of any of one of them having national

$85 I d$. at 133 .

$86 \mathrm{Id}$. at $\mathrm{I} 34$.

87 The reasons are: (a) the district court's injunction ran only against these three federal defendants, and the district court specifically held that the Secretary of the Interior was not an indispensable party, id. at 137; (b) the district court's legal conclusions focused on the defendants' authority vis-à-vis the plaintiffs, not others, $i d$. at $137-38$; (c) the defendants found many faults in the injunction, see id. at $142-44$, including the first part of the injunction, but without any suggestion it erroneously protected nonparties; and (d) the Panama Refining Company's brief in the Supreme Court described the injunction it won in plaintiff-protective terms:

[A]ppellants were entitled to an injunction against the further enforcement of said regulations against them, and the further interference by the agents of the Department of the Interior, acting under the purported authority of said regulations, with the appellants in carrying on their business of producing, storing, and refining oil, and the transportation thereof in intrastate commerce.

Brief for Appellants at 8, Panama Refining Co. (No. I35). Moreover, other district courts appear not to have understood it as having broader effect. See, e.g., United States v. Mills, 7 F. Supp. 547, 553 n.2 (D. Md. I934).

88 Robert H. JACKSON, THE STRUGgle For JUdiClal SuPREMACY: A STUDY OF A CRISIS IN AMERICAN POWER POLITICS II5 (I94I). The book was published in I94I, the year Justice Jackson was confirmed to the Supreme Court.

89 Id. Seeing the government burdened by injunctions "too readily granted," Professor Sidney Post Simpson made the adventuresome suggestion of a bill of peace - for a federal agency, against all its challengers. See Sidney Post Simpson, Fifty Years of American Equity, 5० HARV. L. REV. I 7 I , 246-47 (I 936); see also id. at 246 n.440 (recognizing that federal legislation might be needed).

90 DeP'T of Justice, InJunctions in Cases Involving ACTS OF Congress, S. Doc. No. $75-42$, at I (Ist Sess. I 937 ).

91 Letter from Homer Cummings, U.S. Att'y Gen., to President of the Senate of the United States (Feb. I7, I937), reprinted in DEP'T OF JUSTICE, supra note 9o, at $\mathrm{WI}$ (enclosing the report). 
scope. This is a dog that didn't bark: if the district courts had been issuing national injunctions, the silence of the report would be inexplicable. $^{92}$ To the contrary, the report repeatedly describes injunctions as restricting the application of a statute to a particular party. ${ }^{93}$ The injunctions did severely impede the national government's efforts to enforce New Deal legislation. But that impediment came from the quantity of injunctions, the quantity of the plaintiffs in some individual cases, and the force of precedent dissuading federal officers from enforcing a statute. $^{94}$ Even at this point in American constitutional history - a point at which lower courts were famously "reckless, partisan, and irresponsible" in their award of injunctions against the national government ${ }^{95}$ - the pattern remained one of plaintiff-protective injunctions.

Almost two decades later, in Youngstown Sheet \& Tube Co. $v$. Sawyer, the district court issued a preliminary injunction that did not restrain the seizure of all steel mills. In its initial form, the preliminary injunction protected all the plaintiffs save one. ${ }^{96}$

92 The same potent argument from silence holds for then-Attorney General Jackson. He severely criticized the lower federal courts for their overreaching, see JACKSON, supra note 88, at I I 5-23, but he never raised an objection to the scope of the injunctions.

93 See DEP'T OF JUSTICE, supra note 9o, at 3 (describing injunctions against the processing tax under the Agricultural Adjustment Act); $i d$. at 40 ("The effect of the injunctions or restraining orders granted by the district courts of California and in the District Court for the Southern District of Ohio is to relieve those particular taxpayers from paying taxes presumably due on their processing of coconut oil."); $i d$. at 45 ("The effect of such injunctive relief as has been granted on the operation and enforcement of the internal-revenue law has been confined to restraining that enforcement only as to the particular complainant bringing the suit."); id. at 52 ("The effect of the injunctions [against enforcement of the Kerr-Smith Tobacco Act] was to relieve those particular taxpayers from paying the taxes imposed."); id. at 63 (noting in suits challenging loans for municipal power plants made pursuant to the National Industrial Recovery Act that "[t]he effect of the restraining orders and injunctions issued in these cases has been to delay or impede the construction of the particular projects concerned"); $i d$. at 88-89 (noting that three federal district courts issued fifty-nine injunctions restraining the collection of the windfall taxes, which "relieved these plaintiffs from filing their returns," id. at 89 ).

94 See, e.g., id. at 37 (noting, with respect to suit by approximately 2200 cotton producers to enjoin collection of tax under the Bankhead Cotton Control Act, that "[t]he granting of the injunctions paralyzed the Government's efforts to enforce the Bankhead Act in Georgia'); id. at 38 (observing that the grant of injunctions in more than a hundred cases challenging the tax under the Bituminous Coal Conservation Act "made it impossible to enforce the act, and no effort was made to enforce it even against companies which had not brought suit"); $i d$. at 59 (attributing the lack of enforcement of the National Industrial Recovery Act in the months preceding Schechter Poultry to the fact that "a number of lower courts had held the act unconstitutional," and noting that cause may be attributable "as much to the decisions denying the constitutionality of the act as to the fact that injunctions were granted restraining its enforcement"); see also id. (noting that when a district court enjoined a prosecution under the National Industrial Recovery Act, federal prosecutors would not engage in "further prosecution in that district").

95 JACKSON, supra note 88 , at 123 (denouncing this "picture of judicial supremacy at work in the district courts of the United States").

96 Youngstown Sheet \& Tube Co. v. Sawyer, I03 F. Supp. 569, 577 (D.D.C. I952); HENRY M. HART JR. \& Herbert Wechsler, The Federal Courts AND THE FEderal SyStem I $204-05$ (I 953). That one plaintiff was the United States Steel Company; it had sought a narrower 
A single case from the federal courts' first century and a half does not fit this pattern. In Hammer v. Dagenhart, ${ }^{97}$ corporations opposed to the federal child labor statute organized a challenge in the Western District of North Carolina. ${ }^{98}$ The plaintiffs they selected were two brothers, one fifteen and one thirteen, and the boys' father. The federal district judge held the law unconstitutional and granted the injunction the plaintiffs requested - an injunction restraining the enforcement of the statute within the Western District of North Carolina. ${ }^{99}$ The injunction thus went further than merely prohibiting enforcement against the plaintiffs. ${ }^{100}$ The Attorney General directed federal district attorneys to continue to bring prosecutions under the statute outside the Western District of North Carolina. ${ }^{101}$ The case was appealed directly to the U.S. Supreme Court, which affirmed, ${ }^{102}$ but without discussing the remedy.

At least in theory, the injunction in Hammer v. Dagenhart was a substantial deviation from equity practice. Once an injunction can protect nonparties (as opposed to protecting only the plaintiffs), it is a matter of judicial grace how far it extends. The territorial boundaries of the court are not a sound limit, for it has long been established that equity can enjoin extraterritorial acts. ${ }^{103}$ Nevertheless, the injunction in Hammer v. Dagenhart seems to have been an aberration more than the start of a new practice. The district court proceedings were sloppy; despite the importance of the case, the judge did not even issue a written opinion. ${ }^{104}$ Subsequently, when Congress passed a tax on child labor and it was challenged - not coincidentally - before the same district judge, he issued an injunction restraining the collection of the tax only as to the plaintiffs. ${ }^{105}$ Moreover, it is worth emphasizing that the plaintiffs in Hammer v. Dagenhart did not seek, and the court did not award, a national injunction. This seems clearly to be because the corporate funders of the litigation did not think a national injunction was possible: mill owners from out of state, including those of South Carolina, would have wanted a national injunction. ${ }^{106}$

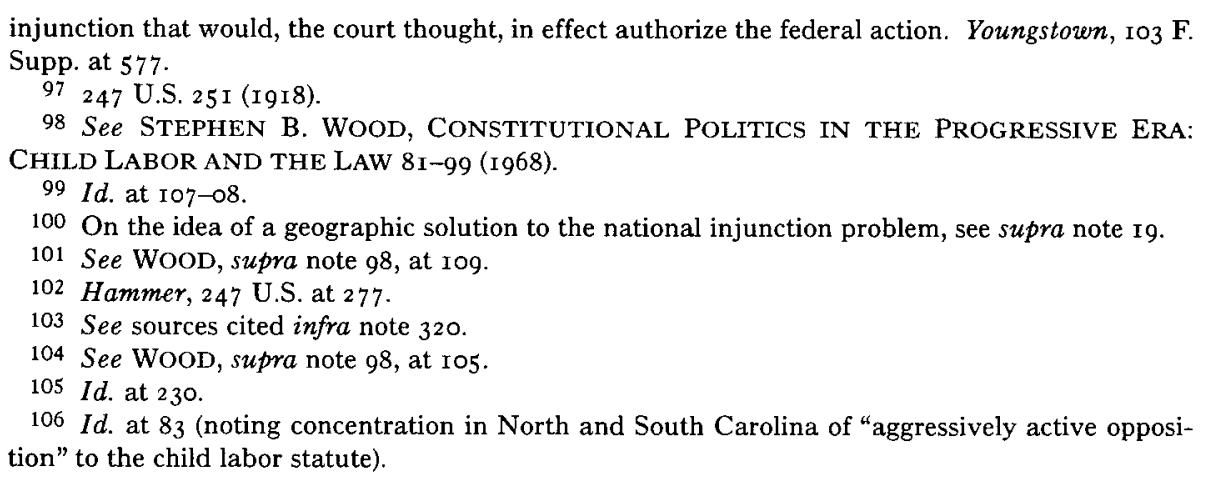


There is a coda to the story of Hammer v. Dagenhart. Counsel for Mrs. Frothingham argued that in previous cases the Court had "permitted a proceeding to be maintained by one of a large class affected by a law alleged to be invalid, for the purpose of enjoining a public officer." ${ }^{107}$ Of the authorities cited by her counsel, only one case involved a federal statute operative outside the District of Columbia: Hammer $v$. Dagenhart. ${ }^{108}$ If there was any chance that it should be taken to support a national injunction, the idea was decisively rejected in Frothingham v. Mellon.

2. The Emergence of National Injunctions (from the Ig6os). Through the middle of the twentieth century, there do not appear to have been any national injunctions. Soon the national injunction would seem possible, but still not widely accepted. Consider three cases in this in-between time: Wirtz v. Baldor Electric Co. ${ }^{109}$ (I963), Flast v. Cohen ${ }^{110}$ (1968), and Harlem Valley Transportation Association v. Stafford ${ }^{111}$ (1973).

In Wirtz, a panel of the D.C. Circuit conditionally enjoined the use of a determination by the Secretary of Labor about the prevailing wage in the electrical promoters and generators industry. ${ }^{12}$ The court, consisting of Chief Judge Bazelon and Judges Washington and Wright, had found the Secretary's determination invalid. ${ }^{113}$ It was less clear that any of the plaintiffs had standing, so the court remanded for further proceedings on that point in the district court. ${ }^{14}$ But the D.C. Circuit panel nevertheless went ahead and resolved the scope of the injunction, conditional on the district court finding standing. ${ }^{115}$ The panel's conclusion was clear: even though the suit was not certified as a class action, ${ }^{116}$ the Secretary should be enjoined from relying on his determination of the industry wage as to any business in the industry, not merely as to the three plaintiffs. ${ }^{117}$ Strikingly, the court cited no previous example of such an injunction. Instead, it offered four arguments:

107 Frothingham, 262 U.S. 447, 475 (I923) (argument of William L. Rawls).

108 Id. Two other cases were cited by counsel. Truax v. Raich, 239 U.S. 33 (1915), was a constitutional challenge to a state statute with a prayer for injunctive relief that would protect only the plaintiff. See Transcript of Record at 18-19, Truax, 239 U.S. 33 (No. 36I). Millard v. Roberts, 202 U.S. 429 (I906), was a constitutional challenge to the expenditure of federal taxpayer money in the District of Columbia, $i d$. at 436 , which the Court resolved even while expressly reserving whether "a taxpayer of the District of Columbia[] can raise the questions we have considered," $i d$. at 438.

109337 F.2d 5 I8 (D.C. Cir. 1963).

110392 U.S. 83 (I968).

111360 F. Supp. 1057 (S.D.N.Y. I973).

112 Wirtz, 337 F.2d at 520, 533-35.

$113 \mathrm{Id}$. at $53 \mathrm{I}$.

114 Id. at 533.

115 Id. at 535.

116 Id. at 533 \& n.34.

117 Id. at 534-35. 
First, the rule of law required intercase consistency: a "court would ordinarily give the same relief to any individual who comes to it with an essentially similar cause of action against the administrator."118 True, but beside the point. That the court would give an injunction to protect someone else, if that person sued and won, does not establish the correctness of giving that person a remedy in the absence of suit.

Second, the court noted the potential for the Secretary to apply inconsistent standards, giving some firms a competitive advantage. ${ }^{119}$ The risk was real, but the court assumed an inert and unresponsive agency.

Third, the court pointed to the language in the Administrative Procedure Act"120 (APA) instructing a court to "hold unlawful and set aside" agency actions it finds to be invalid. ${ }^{121}$ Yet the court seemed to recognize that the argument proved too much; it quickly retreated to emphasizing its discretion about the scope of relief, which was to be determined by various "legal and equitable considerations."122

Fourth, the court analogized the Secretary's determination to a statute held unconstitutional, which it noted would "be regarded as unconstitutional as to all persons similarly situated."123 This argument sidestepped a key point: "regard[ing a statute] as unconstitutional" is not the same thing as enjoining its enforcement against anyone. ${ }^{124}$

Wirtz appears to have been the first national injunction in the United States. ${ }^{125}$ Several points about it are especially remarkable. One is that the court cited no prior cases that offered support for the scope of the remedy. Another is that it anticipated the arguments that continue to

\footnotetext{
$118 I d$ at 534

119 Id. For earlier recognition of this possibility, see supra note 60 .

120 Ch. 324,60 Stat. 237 (r946) (codified as amended at 5 U.S.C. $\$ \$ 551,553-559,701-706$ ).

121 Wirtz, 337 F.2d at 534 (emphasis omitted) (quoting 5 U.S.C. \& Ioog(e)(B) (I 958)). National injunctions were not contemplated when the APA was enacted. No court had previously given a national injunction. Indeed, it was not even contemplated that there would be widespread use of agency rulemaking: "Before the I 960 s agencies acted mainly through case-by-case adjudications." Reuel E. Schiller, Rulemaking's Promise: Administrative Law and Legal Culture in the rg6os and I970s, 53 ADMIN. L. REV. I I39, I I 45 (200I). This expectation - that agencies would generally make policy through adjudication - is consistent with the choice of "set aside" in the text of the APA, for in prior judicial usage the phrase was used for reversing judgments. See, e.g., Morgan v. Daniels, I 53 U.S. I20, I 24-25 (I 894). (On the likely anachronism of reading "set aside" as synonymous with "strike down," see infra section II.B, pp. 449-52.) In short, whatever one's view of how much the APA codified or changed existing practice, it never speaks with the clarity required to displace the longstanding practice of plaintiff-protective injunctions. See Nken v. Holder, 556 U.S. 4I 8, 433 (2009) (presuming that statutes conform to longstanding remedial principles).

122 Wirtz, 337 F.2d at 534 .

123 Id. (emphasis added).

124 In support of this strained argument, the best the court could do was to cite two cases that allowed third-party standing, Truax v. Raich, 239 U.S. 33, 38-39 (1915), and Pierce v. Society of Sisters, 268 U.S. 5 10 (1925). Wirtz, 337 F.2d at 534

125 I am grateful to Professor Michael Morley for bringing the case to my attention.
} 
be invoked in favor of the national injunction - arguments about consistency between cases, about fragmentation in the law, and about the APA. Finally, Wirtz seems to have been a pebble that sunk without causing any ripples: no subsequent cases noted the scope of the remedy in Wirtz.

Later in the rg6os came Flast $v$. Cohen, a suit challenging the federal government's expenditure of tax money. As in Frothingham, the complaint requested a national injunction. ${ }^{126}$ Also as in Frothingham, because the suit was about federal expenditure of tax money, it would not be possible to give the plaintiffs relief that involved only the taxes they paid. By the time the case arrived at the Supreme Court, however, the plaintiffs seem to have conceded that a national injunction would not be appropriate and were suggesting that they wanted an injunction only for New York City. ${ }^{127}$ But the Supreme Court did not hold them to that concession, and expressly contemplated that the injunction might apply beyond New York City programs. ${ }^{128}$

In Flast, the Court never endorsed a national injunction, but it certainly did not reject the possibility out of hand, as Frothingham had done. The mention of the scope of the injunction came in the Court's discussion of the procedural posture of the case (and its analysis of whether a three-judge district court was properly convened). ${ }^{129}$ In deciding the substantive issue in the case - whether plaintiffs could sue in federal court - the Justices treated the question as one entirely about "standing." In fact, how the Court read Frothingham was telling. The Court divvied up different parts of Frothingham, allocating them to buckets of "constitutional rule"130 and "pure policy"131 but ignoring all questions of federal power to grant equitable remedies. Indeed, Flast

126 Appendix at 5a, Flast v. Cohen, 392 U.S. 83 (I968) (No. 4I6) ("This is a civil action brought by the plaintiffs, on their own behalf and on behalf of all others similarly situated, for a temporary and permanent injunction against the allocation and use of the funds of the United States to finance, in whole or in part, instruction in sectarian schools, and to declare such use violative of the First and Fifth Amendments to the Federal Constitution.").

127 See Flast, 392 U.S. at 89 ("[N]oting that appellants have conceded that the case should be deemed one limited to the practices of the New York City Board of Education, the Government contends that appellants wish only to forbid specific local programs which they find objectionable and not to enjoin the operation of the broad range of programs under the statutory scheme.").

128 See id. ("It is true that the appellants' complaint makes specific reference to the New York City Board of Education's programs which are funded under the challenged statute, and we can assume that appellants' proof at trial would focus on those New York City programs. However, we view these allegations of the complaint as imparting specificity and focus to the issues in the lawsuit and not as limiting the impact of the constitutional challenge made in this case. The injunctive relief sought by appellants is not limited to programs in operation in New York City but extends to any program that would have the unconstitutional features alleged in the complaint." (emphasis omitted))

129 See id. at 88-9I.

130 Id. at 92

131 Id. at 93 
almost entirely ignored questions of remedy. It no longer seemed unthinkable that there would be a national injunction.

The next step was taken in Harlem Valley Transportation Association v. Stafford. The Natural Resources Defense Council and other plaintiffs sued several government defendants, including the Interstate Commerce Commission, about precisely when the ICC needed to produce environmental impact statements in railroad-abandonment proceedings. ${ }^{132}$ The plaintiffs argued that the ICC was failing to comply with its legal duties by waiting to produce the statement until the hearing itself, at which point environmentalist intervenors were not in a position to effectively challenge the conclusions in the statement. ${ }^{133}$

As the case unfolded, there was some confusion about what the scope of the relief would be. The plaintiffs emphasized environmental harms in the Northeast, and in particular the Harlem Valley. ${ }^{134}$ The plaintiffs also asked for class certification on behalf of all who would be harmed by the ICC's failure to timely produce the required statements. ${ }^{135}$ Judge Frankel was obviously concerned about whether he had power to issue a broad injunction if a class was not certified, yet the government defendants conceded the point. As Judge Frankel said in his opinion accompanying the preliminary injunction:

One of the court's main concerns during the hearing of the motion for a preliminary injunction was the question whether the plaintiffs, if they could prove entitlement to any relief, could legitimately seek a restraint of nationwide effect when their alleged interests might be of narrower geographic scope. Both the United States and the ICC have now not only conceded, but insisted, that a preliminary injunction in this case would "affect the agency in the entire scope of its authority and jurisdiction."136

Given this concession, Judge Frankel decided that "[i]n these circumstances, it becomes unimportant to decide at this early stage whether the action may proceed as a class suit." ${ }^{137}$ He granted a preliminary injunction, ${ }^{138}$ and the Second Circuit affirmed with no further discussion of the scope of injunctive relief. ${ }^{139}$ That was that.

\footnotetext{
132 See Harlem Valley Transp. Ass'n v. Stafford, 360 F. Supp. 1057, I059 (S.D.N.Y. i 973).

133 See id. at 1061.

134 Id. at 1060, 1064.

135 See id. at 1060.

136 Id. at I060 n.2 (quoting Defendants' Supplemental Memorandum at 4, Stafford, 360 F. Supp. I057 (No. 73 Civ. 1330)). Judge Frankel added the following quotation from the brief of the government defendants: "Any action by this Court based on plaintiffs' individual interests and the public interest will affect the agency's procedures and the application of said procedures anywhere within the scope of the agency's jurisdiction." I $\dot{d}$. (quoting Defendants' Supplemental Memorandum, supra, at 4-5).

137 Id.

$138 I d$. at $1065-66$.

139 See Harlem Valley Transp. Ass'n v. Stafford, 500 F.2d 328, 332-37 (2d Cir. 1974).
} 
The district court had backed into a national injunction without any real consideration. Multiple points made the decision an odd formative moment. One is the government's concession, which should not have been decisive. A court's equity powers are not determined by the concessions of the parties; many equitable doctrines protect the public and the court itself. ${ }^{140}$ One of the defendants (the Department of Justice) actually agreed with the plaintiffs on the merits. ${ }^{141}$ The merits had already been decided in an earlier Second Circuit case, as the ICC had previously admitted ${ }^{142}$ - an admission it was now trying to escape with implausible distinctions. And as for the remedy, the case was not even an appropriate one for an injunction. Because the government defendants had indicated that they would comply and there was no need to manage that compliance, the court should instead have granted a declaratory judgment. ${ }^{143}$

The decision by the district court in Stafford was affirmed the next year by the Second Circuit. Intervening developments explain the court's willingness to affirm a national injunction, and especially important were two opinions by Judge Friendly. First, there was a case that had been brought by five plaintiffs against the Civil Service Commission of the City of New York, alleging that its requirements for new firefighters were racially discriminatory. ${ }^{144}$ Second, a case had been brought by two applicants for unemployment benefits challenging a New York state agency's rule that no benefits could be paid to those who moved to a place with "high persistent unemployment" (in this case, Puerto Rico). ${ }^{145}$ In neither case was class certification appropriate: in the former because of the inadequacy of the representatives ${ }^{146}$ and in

140 See Samuel L. Bray, The System of Equitable Remedies, 63 UCLA L. REV. 530, $572-86$ (2016); Seana Valentine Shiffrin, Remedial Clauses: The Overprivatization of Private Lav, 67 HASTINGS L.J. 407, 4II (2016) (referring to "the public's interest in reserving remedial decisionmaking to impartial adjudicators who are positioned to tailor remedies with sensitivity to the details of the circumstances and significance of a breach").

141 See Stafford, 360 F. Supp. at 1065.

142 See id. at $1062-64$.

143 See Samuel L. Bray, The Myth of the Mild Declaratory Judgment, 63 DUKE L.J. Iog I, I I4445 (20r4).

144 Vulcan Soc'y of the N.Y.C. Fire Dep't, Inc. v. Civil Serv. Comm'n, 490 F.2d 387 (2d Cir. 1973). The requirements challenged by the plaintiffs included some that affected them, such as a written examination, and some that did not affect them, such as a diploma requirement and a conviction bar. $I d$. at 399 . The district judge himself said there was "serious question as to whether any of the plaintiffs have standing to challenge" the latter requirements. Vulcan Soc'y of the N.Y.C. Fire Dep't, Inc. v. Civil Serv. Comm'n, 360 F. Supp. I265, 1277 n.35 (S.D.N.Y. 1973). The district judge decided the written examination was unconstitutional and enjoined its use by the city. $I d$. at I $277-78$. The district judge reached the merits without deciding the motion for class certification. Id. at $\mathrm{I} 266 \mathrm{n} . \mathrm{I}$

145 Galvan v. Levine, 490 F.2d I255, I257 (2d Cir. 1973).

146 See Vulcan Soc'y, 490 F.2d at 399-400 
the latter because of the difficulty of administering relief on a class basis. ${ }^{147}$

Aware that these suits were imperfect vehicles, Judge Friendly nevertheless strongly encouraged the municipal and state defendants to give up the discriminatory rules. In doing so, he blurred the distinction between what the court's decree required the defendant to do and what the defendant chose to do. In the firefighter case, Judge Friendly said it would be "unthinkable" for a losing municipality to "insist on other actions being brought." 148 Judge Friendly also advised the plaintiffs about how to perfect their case, suggesting that if class certification were denied on remand, the complaint could be amended to include other plaintiffs, in order to ensure that there were some plaintiffs affected by each of the challenged requirements. ${ }^{149} \mathrm{He}$ added, now advising the city of New York: "If we may be pardoned for speaking practically, we cannot understand why the municipal defendants should resist such an amendment."150 "It is evident," he said, that these points "will be raised sooner or later, and ... it is in everyone's interest that questions about them should be promptly resolved." 151 In the unemployment benefits case, Judge Friendly treated the judgment as running to the benefit of similarly situated parties merely because the state defendants chose to comply. ${ }^{152}$

Once the distinction between legal and practical effect was collapsed, and once the state defendants had signaled they would acquiesce, it no longer seemed to matter who the plaintiffs were, and one plaintiff could get a universal injunction. As Judge Friendly said, "insofar as the relief sought is prohibitory, an action seeking declaratory or injunctive relief against state officials on the ground of unconstitutionality of a statute or administrative practice is the archetype of one where class action designation is largely a formality, at least for the plaintiffs." 153 All of these assertions from Judge Friendly were dicta, and if read carefully they did not sharply contradict the traditional equitable practice. "Practical" advice about what a government defendant should do is one thing, and the "legal" effect of a remedy or judgment is another. Even Judge Friendly's reference to the class action designation being a "formality" was given two careful qualifications: "largely a formality, at least for the

\footnotetext{
147 Galvan, 490 F.2d at 1262.

148 Vulcan Soc'y, 490 F.2d at 399.

149 See id. at 400 .

150 Id.

$151 \mathrm{Id}$.

152 Galvan, 490 F.2d at I26I ("The State has made clear that it understands the judgment to bind it with respect to all claimants; indeed even before entry of the judgment, it withdrew the challenged policy even more fully than the court ultimately directed and stated it did not intend to reinstate the policy.").

153 Id.
} 
plaintiffs." ${ }^{154}$ That is denotatively true, because named plaintiffs do typically receive the same injunctive relief regardless of whether a class is certified. But for defendants and nonparties, it matters what the scope of the injunction is. The hedges and qualifications were oversubtle.

Unsurprisingly, these opinions by Judge Friendly were taken to stand for the proposition that class certification does not matter for injunctive relief. ${ }^{155}$ One plaintiff gets the same injunction that a class of plaintiffs would. Once that proposition was accepted, it was an easy matter to apply it in a suit against the national government. That is what the Second Circuit did the next year - implicitly and without any express discussion - when it affirmed the national injunction in Harlem Valley Transportation Association v. Stafford. ${ }^{156}$

Hard procedural cases make bad law. Judge Friendly recognized this in the firefighters case, when he noted that the district court judge had decided the case without even ruling on the motion for class certification, adding that "the judge's commendable desire to get at the heart of the complaint seems to have created a bit of a procedural impasse."157 Yet Judge Friendly's opinions also created an impasse. Stripped of the hedges and qualifications, the principle is that an injunction can protect nonparties. It is true that one could draw a line after municipal defendants, given the history of broad equitable relief against them; ${ }^{158}$ or one could draw a line after state defendants, for pragmatic reasons. ${ }^{159}$ But if those lines are not drawn, a national injunction is simply a matter of carrying the principle to its logical conclusion. That is what courts have done over the subsequent decades as they have issued national injunctions.

$154 I d$. (emphases added). Note that Judge Friendly similarly hedged a conclusion in the firefighter case: '[The district judge] was entirely right in thinking it unnecessary, from the plaintiffs' standpoint, for him to decide on class action designation in order to pass upon the issues raised in regard to Exam OI 59." Vulcan Soc'y, 490 F.2d at 399 (emphasis added). For that proposition, Judge Friendly cited two Fifth Circuit cases, one of which, Bailey v. Patterson, 323 F.2d 201 (5th Cir. r 963 ), is discussed below at note 225 .

155 Five relatives of servicemen missing in action in Vietnam sued the Secretaries of the Air Force, Army, and Navy, challenging the statutes that determined when missing servicemen were declared dead. McDonald v. McLucas, 37 I F. Supp. 83 I (S.D.N.Y. 1974). The district court denied class certification on the ground that it would be "largely a formality," id. at 833 , because "[t]he court can properly assume that an agency of the government would not persist in taking actions which violate the rights of a service member's next of kin, if the statutes are declared unconstitutional," $i d$. at 834 . The authority cited? The two Friendly opinions and a district court opinion relying on one of the Friendly opinions. See id. at $833-34$. The result? The district court held two provisions of the U.S. Code unconstitutional and issued a national injunction against their enforcement. Id. at 837 .

156500 F.2d 328 (2d Cir. I974).

157 Vulcan Soc'y, 490 F.2d at 399

158 See supra notes 68-69 and accompanying text.

159 See supra note 29 and accompanying text. 
National injunctions were not immediately widespread. ${ }^{160}$ But in time there were a number of cases in which federal courts issued them. ${ }^{161}$ In other cases, federal courts have declined to give national injunctions. ${ }^{162}$ There is no rule against national injunctions; nor is there a rule requiring them. In fact, a district judge can find authority supporting any possible decision about the scope of the injunction. When courts want to grant injunctions that go beyond protecting the plaintiffs, they point to the extent of the violation, ${ }^{163}$ the permissibility of injunctions benefitting nonparties, ${ }^{164}$ the impracticality of giving an injunction benefitting only the plaintiffs, ${ }^{165}$ and the need for complete relief. ${ }^{166}$ When courts want to grant injunctions that protect only the plaintiffs, they point to the importance of allowing other federal courts to reach their own decisions ${ }^{167}$ and the principle that equitable remedies should be no more burdensome than necessary. ${ }^{168}$ As with Professor Karl

160 In 1977 , a commentator could treat federal agencies' practice of nonacquiescence - accepting defeat one circuit at a time, while continuing to apply and defend a challenged regulation in other circuits - without ever discussing the possibility that an injunction might bind the agency throughout the United States. Allan D. Vestal, Relitigation by Federal Agencies: Conflict, Concurrence and Synthesis of Judicial Policies, 55 N.C. L. REV. 123 (1977).

161 E.g., Nat'l Mining Ass'n v. U.S. Army Corps of Eng'rs, I45 F.3d I399, 1409-10 (D.C. Cir. I 998) (affirming national injunction against agency rule under Clean Water Act); Bresgal v. Brock, 843 F.2d I I63, I I68-72 (9th Cir. I987) (affirming with revision a national injunction requiring the Secretary of Labor "to cease refusing to enforce the Migrant and Seasonal Agricultural Workers Protection Act," id. at II $7 \mathrm{I}$, with respect to forestry workers); see also Davis v. Astrue, $874 \mathrm{~F}$. Supp. $2 \mathrm{~d} \mathrm{856,868-69}$ (N.D. Cal. 2012) (deferring ruling about whether individual plaintiffs could obtain "systemwide" relief in suit against the Social Security Administration, id. at 868 , but noting its availability). More recent examples are cited infra section III.A, pp. 457-6r. Courts routinely reach similar decisions in suits against state and municipal government officers. See, e.g., Clement v. Cal. Dep't of Corr., 364 F.3d I 148, I I 52-54 (9th Cir. 2004) (state); Soto-Lopez v. N.Y.C. Civil Serv. Comm'n, 840 F.2d I62, I68-69 (2d Cir. 1988) (municipality). Other cases are listed in Siddique, supra note 6; and Berger, supra note 6.

162 E.g., Va. Soc'y for Human Life, Inc. v. FEC, 263 F.3d 379, 392-94 (4th Cir. 2001); Meinhold v. U.S. Dep't of Def., 34 F.3d I469, I480 (9th Cir. I994); Zepeda v. INS, 753 F.2d 7 I9, 728 n.I (9th Cir. 1983).

163 E.g., Texas v. United States, 20I F. Supp. 3d 810, 836 (N.D. Tex. 2016).

164 E.g., Bresgal, 843 F.2d at i 69.

165 E.g., $i d$. at $1169-72$.

166 E.g., Washington v. Reno, 35 F.3d 1093, I 103-04 (6th Cir. 1994) (upholding national preliminary injunction against the Bureau of Prisons, which had been issued before class certification, on the grounds that "[t]he named plaintiffs' gains in obtaining an injunction . . . would be illusory," $i d$. at I I04, if it were limited to controlling the actions of the Bureau of Prisons only at their own prison); Davis, 874 F. Supp. 2d at $867-69$ (denying motion to dismiss non-class action against the Social Security Administration and noting the possibility of a national injunction where necessary "for the plaintiffs to get effective relief," $i d$. at 868 ).

167 E.g., Va. Soc'y for Human Life, 263 F.3d at 393-94.

168 E.g., id. at 393; see also Ryan C. Williams, Due Process, Class Action Opt Outs, and the Right Not to Sue, I 5 COLUM. L. REV. 599, 650-5 I (20I5). 
Llewellyn's famous dueling canons, ${ }^{169}$ there is always a principle on each side. ${ }^{170}$

\section{WHY DID THE NATIONAL INJUNCTION EMERGE?}

This Part offers an explanation for the national injunction. The explanation is historical, and it blends doctrine, the institutional structure of courts, and ideology (in the sense of changes in intellectual fashion regarding law and the judicial role). The necessary condition for the problems associated with the national injunction was a structural change: the shift from a one-chancellor system to a multiple-chancellor system. For the federal courts, that shift occurred in I789. The shift to multiple Chancellors was necessary but not sufficient to create the forum-shopping and conflicting-injunction problems.

What made the vulnerabilities of the multiple-chancellor system manifest were two ideological shifts. The first was a shift in the conception of injunctions against federal officers, from thinking of them as essentially antisuit to thinking of them as freestanding challenges to a statute, regulation, or order. The second was a shift in the conception of legal invalidity, from an invalid law being one a judge merely failed to apply because a higher law controlled, to the conception of a judge "striking down" and thus removing from operation an invalid law. In addition to these two ideological shifts, there were other changes that might have made national injunctions seem more natural: familiarity with statutes that concentrated judicial review in a single court, greater use of federal agency rulemaking and pre-enforcement challenges, and renewed judicial confidence after Brown v. Board of Education.

The account given here - an institutional shift followed much later by ideological changes that exploited its vulnerability - matters in several ways, even apart from its intrinsic interest. One is that it suggests the national injunction is relatively entrenched. It rests on structural and ideological forces that will not soon be leaving the scene. That suggestion will in turn shape the solution proposed in Part V. Another way the explanatory account matters is that it reveals a difficulty in translating traditional equitable doctrines for the present. Those doctrines were developed in a very different institutional setting - a onechancellor system - and so they need to be developed and refined with awareness of the multiple-chancellor system of the federal courts.

169 Karl N. Llewellyn, Remarks on the Theory of Appellate Decision and the Rules or Canons About How Statutes Are to Be Construed, 3 VAND. L. REV. 395 (I950). For a response to Llewellyn, see Antonin Scalia, Common-Law Courts in a Civil-Law System: The Role of United States Federal Courts in Interpreting the Constitution and Laws, in A MATTER OF INTERPRETATION 3, 26-27 (Amy Gutmann ed., 1997).

170 See Carroll, supra note 6, at 2033 ; see, e.g., Davis, 874 F. Supp. 2 d at 868 (finding the conflicting authority about the scope of an injunction "difficult to square"). 


\section{A. The Structural Precondition: Multiple Chancellors}

Although Chancery began sometime around the Norman invasion, ${ }^{171}$ only gradually did the Chancellor take on duties that were recognizably judicial. Through the fourteenth and fifteenth centuries, it became increasingly clear that Chancery was a court - a one-judge court. ${ }^{172}$ True, the Chancellor was assisted by officers such as "masters" and "registers." For judicial decisionmaking purposes, however, Chancery was a unitary institution. It was the Chancellor who had to sign all of the decrees; they were his decrees. ${ }^{173}$ There was no appeal from the Chancellor; his jurisdiction thus resembled, in more familiar terms, the original jurisdiction of the Supreme Court of the United States. This sense of Chancery as a unitary institution is captured, in this Article, by saying that there was one Chancellor. ${ }^{174}$

The fact that there was one Chancellor was burdensome to those who sought the Chancellor's aid, and to the Chancellor himself. For example, the Chancellor had to make allowance for those who lived in distant parts of England, because it would take so long for them to reach the capital after being served with a subpoena. ${ }^{175}$ And to ease the

171 See BAKER, supra note 8 , at $99 \&$ n.I 5 .

172 On the growth of the Chancellor's English jurisdiction in the fourteenth century, see $i d$. at IOI-O3. On the increasing significance of Chancery as a court in the fifteenth century, see P. Tucker, The Early History of the Court of Chancery: A Comparative Study, I I5 ENG. HIST. REV. 79I, 79I95 (2000).

173 For example, when Francis Bacon was Chancellor (I6I $7-I 62 I$ ), he instructed the registers, who drafted the decrees, that when they gave decrees to him for his signature, they "ought to give him understanding which are [the] decrees of weight, that they may be read and reviewed before his lordship sign them." FRANCIS BACON, Ordinances Made by the Lord Chancellor Bacon, reprinted in 7 THE WORKS OF FRANCIS BACON 765 (James Spedding, Robert Leslie Ellis \& Douglas Denon Heath eds., London, Spottiswoode \& Co. 1859) (Ordinance 4I). Thus the press of Chancery business meant the Chancellor would issue more decrees than he could read, but he was still responsible for every decree. For a recent case emphasizing that federal judges should not cede to masters the power to fill in the details of an injunction, see City of New York v. Mickalis Pawn Shop, LLC, 645 F.3d I I 4, I45-46 (2d Cir. 201 I).

174 Qualifications could be added. One is that the Chancellor retained his administrative duties, which means that one could say that instead of one Chancellor there was only three-eighths of a Chancellor. Another is that there were lesser courts of equity, including the Court of Requests and the Court of Exchequer. The Court of Requests did not survive the seventeenth century, but the Court of Exchequer had an equitable jurisdiction lasting into the nineteenth century, and it did issue injunctions. See W.H. BRYSON, THE EQUITY SIDE OF THE EXCHEQUER I I (I 975); JOHN H. LANGBEIN, Renée LETTOW LERNER \& BRUCE P. SMITH, HISTORY OF THE COMMON LAW 3I9-20 (2009). Nevertheless, it seems fair to say that "their use in Exchequer was minor compared to that of Chancery, and did not shape the path along which injunctions were to develop." David W. Raack, A History of Injunctions in England Before I700, 6 I IND. L.J. 539, 562 (I986).

175 Cases in Tempore Egerton (Ch. c. $1599 \times$ c. I604), reprinted in I CASES CONCERNING EQUITY AND THE COURTS OF EQUITY I550-I660, at 318, 337 (W.H. Bryson ed., 200I) ("If a subpoena be sued forth against one that dwells two hundred miles from London, let the plaintiff have this care, that the subpoena be returnable so as he may have the defendant come to London after the rate of twenty miles a day."). Centuries later, in 1858 , the cost and difficulty of traveling to see the one Chancellor would again be discussed when there was a proposal to allow county courts to 
burden on the Chancellor, the early modern Chancery adopted many rules that constrained or channeled would-be plaintiffs. ${ }^{176}$

As England grew, as the common law courts grew, and as the various other equitable courts grew, there remained only one Chancellor. ${ }^{177}$ Not until the nineteenth century, when Chancery was nearing the end of its life as an independent judicial institution, did it receive ViceChancellors who could also hear and decide cases. ${ }^{178}$ At that point Chancery did have multiple judges, but it remained a small, unified, and distinctive institution, and the power to issue equitable remedies was not distributed throughout the English courts.

In colonial America, the one-chancellor system was imitated: "[E]quity courts sat, as a rule, only in the capital; unlike the common law, it was not brought to every man's doorstep."179 That pattern continued in the early Republic; a plaintiff who wanted to see Chancellor Kent typically had to go to Albany. ${ }^{180}$

The late eighteenth century and the nineteenth century saw a shift to multiple-chancellor systems. In federal courts of the new United

exercise equitable jurisdiction. Annual Report of the Council for the Session $1857-8,5$ LAW MAG. \& L. REV. 338, 342 ( 1858 ) (" [] t cannot be doubted that distance from the metropolis often entails on suitors, in many parts of the country, a denial of justice in matters taken cognizance of by a Court of Equity alone....').

176 Many of Bacon's ordinances are instructions to the parties to avoid burdening the court. The grounds for a bill of review (in essence a motion for reconsideration of a Chancery decision) were narrowly specified, BACON, supra note $\mathrm{I} 73$, at 759-60 (Ordinances $3 \& 4$ ), and any party seeking a bill of review had to first obey the Chancellor's decree and obtain sureties for any "costs and dam. ages for the delay" that might result, id. at 760 (Ordinance 5). Moreover, litigants were warned about filing papers of "immoderate length," $i d$. at 767 (Ordinance 55), offering evasive answers, $i d$. at 767-68 (Ordinances 6I \& 63), introducing depositions from unrelated litigation, id. at 769 (Ordinance $7 \mathrm{I}$ ), and attacking the credibility of witnesses, $i d$. (Ordinance 72). Any plaintiff who brought a suit in Chancery without having "probabilem causam litigandi," id. at 766 , had to "pay unto the defendant his utmost costs," id. at 767 (Ordinance 54). Once the Chancellor had decided, orders were not to be "explained upon any private petition, but in court as they are made." Id. at 764 (Ordinance 37 ).

177 As with many aspects of the English political order, there was an exception during the Interregnum between Charles I and Charles II, when the Puritans replaced the Chancellor with a commission but could not, despite repeated efforts, rid themselves of Chancery. Stanley N. Katz, The Politics of Law in Colonial America: Controversies over Chancery Courts and Equity Law in the Eighteenth Century, in LAW IN AMERICAN HISTORY 255, 260-6r (Donald Fleming \& Bernard Bailyn eds., I97 I).

178 D.M. KERLY, AN Historical SKETCH OF THE EQUiTABLE JURISDiCTION OF THE Court of Chancery 272 (Cambridge, Cambridge Univ. Press I89o). Vice-Chancellors were added only after Lord Eldon, the most dilatory of the Chancellors and the inspiration for Dickens's caricature. Id. at 270-7 I. On Dickens's depiction of Chancery in Bleak House, see M.J. LEEMING, Five Judicature Fallacies, in I HISTORICAL FOUNDATIONS OF AUSTRALIAN LAW I69, I 7 I 72 (J.T. Gleeson, J.A. Watson \& R.C.A. Higgins eds., 2013).

179 LAWRENCE M. FRIEDMAN, A HISTORY OF AMERICAN LAW 48 (I973).

180 See John H. Langbein, Chancellor Kent and the History of Legal Literature, 93 COLUM. L. REV. 547, 562-63 (I993) ("In New York, as in England, Chancery was a one-judge court. The Chancellor had his permanent seat in Albany but convened the court twice a year in New York City."). 
States, from the beginning every judge was a Chancellor (that is, every judge could resolve equitable claims on the court's equity side). ${ }^{181}$ Most of the states subsequently distributed equitable powers throughout the judiciary. ${ }^{182}$

In the New York state courts of the nineteenth century, it was the change to multiple Chancellors that allowed the robber barons battling for control of the Erie Railroad to obtain conflicting injunctions. ${ }^{183}$ In the standard account, by President John Quincy Adams's grandson, the blame is squarely put on the multiple Chancellors of I860s New York. The state was divided into eight districts, each with four or five elected judges. ${ }^{184}$ Adams writes:

These local judges, however, are clothed with certain equity powers in actions commenced before them, which run throughout the State. As one subject of litigation, therefore, might affect many individuals, each of whom might initiate legal proceedings before any of the thirty-three judges; which judge, again, might forbid proceedings before any or all of the other judges, or issue a stay of proceedings in suits already commenced, and then proceed to make orders, to consolidate actions, and to issue process for contempt, it was not improbable that, sooner or later, strange and disgraceful conflicts of authority would arise, and that the law would fall into contempt. ${ }^{185}$

What Charles F. Adams, Jr., describes was not inevitable. The multiple-chancellor system does not lead inexorably to problems such as forum shopping and conflicting injunctions. But it is a necessary precondition.

\section{B. Two Ideological Shifts}

Why did it take a century and a half after the establishment of the federal courts before the national injunction arrived? The question is

181 See Samuel L. Bray, Equity: Notes on the American Reception, in PHILOSOPHICAL FOUNDATIONS OF THE LAW OF EQUITY (Dennis Klimchuck, Irit Samet \& Henry Smith eds., forthcoming 20r8) (manuscript at 7-8). In states without courts of equity at the Founding, the federal courts would have been the only source of equitable relief. See Geoffrey C. Hazard, Jr., Indispensable Party: The Historical Origin of a Procedural Phantom, 6I CoLUM. L. REV. I254, I 277 (I96I).

182 A summary of the current state of merger of legal and equitable courts in the states can be found in Bray, supra note 140, at 538. For an exemplary study, see Kellen Funk, Equity Without Chancery: The Fusion of Law and Equity in the Field Code of Civil Procedure, New York 1846-76, 36 J. LEGAL HIST. I 52 (20I5).

183 C.F. Adams, Jr., A Chapter of Erie, in Charles F. ADAMS JR. \& HENRY AdAMS, ChaPTERS OF ERIE AND OTHER ESSAYS I-99 (New York, Henry Holt \& Co. I886). I am grateful to Professor Andrew Kull for directing me to A Chapter of Erie. For further discussion, see infra note 267 and accompanying text.

184 Adams, supra note 183 , at 22.

$185 I d$. at 22-23. Although not exactly a case of conflicting injunctions, in Ex parte Young, 209 U.S. I23 (I 908 ), after a federal court issued a temporary injunction prohibiting the Minnesota Attorney General from enforcing a rate regulation against the railroad in which the plaintiffs were stockholders, that Attorney General obtained a writ of mandamus requiring the corporation to comply, id. at 132-34. 
difficult, and the answer here is tentative. With enough judicial restraint or certain ideological views about courts and law, the vulnerabilities of the multiple-chancellor structure would not have been exposed. Yet two ideological shifts - in the sense of changes in thinking about law - made it easier for federal judges to grant national injunctions. ${ }^{186}$

First, judges once thought of injunctions against enforcement not as challenges to the validity of a statute (something offensive) as much as antisuit injunctions (something defensive). ${ }^{187}$ A plaintiff seeking an injunction against public officials would be trying to forestall an enforcement action in which the parties would be reversed. ${ }^{188}$ (That is, the plaintiff seeking an injunction would otherwise have been the defendant in the hypothetical future enforcement action.) The court would decide the validity of a law being applied, but only when there was, and only to the extent that there was, a threatened enforcement action. ${ }^{189}$

The contrast can be overstated, because even as a court granted an antisuit injunction, its rationale for doing so might be that the law was invalid - invalid for general reasons, not for plaintiff-specific reasons. ${ }^{190}$ And modern standing doctrine does require an injury to the

186 In addition to the explanations given in this section, a number of others could be given. These might include the adoption of the Federal Rules of Civil Procedure, as well as the I 962 statute authorizing mandamus for federal district court judges, Mandamus and Venue Act of I962, Pub. L. No. $87-748, \S$ (a), 76 Stat. 744,744 (codified at 28 U.S.C. $\$$ I 36 I (2012)).

187 "Antisuit injunction" is the conventional terminology, see, e.g., John Harrison, Ex Parte Young, 60 STAN. L. REV. 989 (2008), and so it is used here. It is not quite precise, as the Georgia v. Alkins case shows. See supra pp. $4^{28-29}$. In that case the injunction did not restrain Mr. Atkins from bringing a suit, but rather from "further proceeding in the collection of the [tax]," which he planned to do by means of a distress warrant. Georgia v. Atkins, ıo F. Cas. 24I, 24I (C.C.N.D. Ga. 1866) (No. 5350). A broader term such as "anti-enforcement injunction" might be more precise, though it would lose the useful connotation of particular proceedings that is implicit in suit.

188 A small but telling example of this perspective is a heading in WALTER WHEELER COOK, CASES AND MATERIALS ON EQUITY (M.T. Van Hecke ed., 4th ed. I948): not "Challenges to Statutes" but "Immunity from Statutory Control," id. at 236 .

189 Cf. White v. Johnson, 282 U.S. 367, 373 (I93I) ("An answer [to the fourth certified question] would involve merely an examination of the Act and a determination whether on its face it violates the Fifth Amendment. Neither this Court nor the court below is authorized to answer academic questions. The constitutionality of a statute is not drawn into question except in connection with its application to some person, natural or artificial."); Frothingham, 262 U.S. 447, 488-89 (I923) ("Looking through forms of words to the substance of their complaint, it is merely that officials of the executive department of the government are executing and will execute an act of Congress asserted to be unconstitutional ...."Id. at 488.); Fitts v. McGhee, I 72 U.S. 5I6, 529-30 (I899) ("There is a wide difference between a suit against individuals, holding official positions under a State, to prevent them, under the sanction of an unconstitutional statute, from committing by some positive act a wrong or trespass, and a suit against officers of a State merely to test the constitutionality of a state statute, in the enforcement of which those officers will act only by formal judicial proceedings in the courts of the State."); New Orleans Water Works Co. v. New Orleans, I64 U.S. $47 \mathrm{I}, 48 \mathrm{I}$ ( $\mathrm{I} 896)$ ("If an ordinance be passed and is invalid, the jurisdiction of the courts may then be invoked for the protection of private rights that may be violated by its enforcement.").

190 In older cases there are some rather thorough statements about an unconstitutional act not being a law - it is "as inoperative as though it had never been passed." Norton v. Shelby County, 
plaintiff. But the older antisuit view was not merely about injury, as can be seen in Frothingham:

The party who invokes the power must be able to show not only that the statute is invalid but that he has sustained or is immediately in danger of sustaining some direct injury as the result of its enforcement, and not merely that he suffers in some indefinite way in common with people generally. ${ }^{191}$

That is, it is not merely that the plaintiff is injured ("he suffers"), but that there is a threat of enforcement against him, and it is the threatened enforcement that the injunction is meant to prevent. Antisuit thinking about the injunction ran deeper than a mere requirement of injury.

To the extent federal courts thought of injunctions against the enforcement of statutes in antisuit terms, ${ }^{192}$ it is easy to see why they would not give national injunctions. The suit anticipates an enforcement action against this plaintiff; the injunction should protect this plaintiff from that enforcement action. A national injunction in an individual action would be illogical, almost unthinkable.

No one has yet charted exactly when the shift occurred, this shift in thinking of an injunction against enforcement of a federal law primarily in antisuit terms to thinking of it primarily as a challenge to the law itself. It is possible that the adoption in I 934 of the federal Declaratory Judgment Act ${ }^{193}$ encouraged this change in thinking. ${ }^{194}$ If so, then the Act had the effect of broadening federal standing, exactly as Justice Brandeis feared. ${ }^{195}$ And the timing of the Act's adoption would fit the change in thinking from Frothingham to Flast. It may also be that this shift was related to the development of the idea that there is an independent category of "facial challenges." 196

I 8 U.S. 425,442 (I 886). To a reader now, that might sound like a statement about the effect when a court declares a law unconstitutional. But it has less to do with judicial review than with natural law: the unconstitutional act lacked legal force whether a court had spoken or not.

191262 U.S. at 488 (emphasis added).

192 For recent literature on antisuit injunctions and $E x$ parte Young, see Harrison, supra note I 87 ; David L. Shapiro, Ex Parte Young and the Uses of History, 67 N.Y.U. ANN. SURV. AM. L. 69 (20I I); and Stephen I. Vladeck, Douglas and the Fate of Ex Parte Young, 22 YALE L.J. ONLINE I3 (2OI2).

19328 U.S.C. $\$ \$ 220 \mathrm{I}-2202$ (20I2).

194 By its own terms, the Declaratory Judgment Act should not have had this effect. See John Harrison, Severability, Remedies, and Constitutional Adjudication, 83 GEO. WASH. L. REV. 56, 82 n.I30 (2014).

195 Edward A. Purcell, JR., Brandeis and the Progressive Constitution: Erie, THE JUdicial POWER, AND THE POLITICS OF THE FEDERAL COURTS IN TWENTIETHCEN'TURY AMERICA I 24-28, I55 (2000).

196 Cf. Alfred Hill, Some Realism About Facial Invalidation of Statutes, 30 HofSTRA L. REV. $647,653,655-57 \& n_{.3} 8,682$ (2002) ("Traditionally, facial invalidation meant simply that statutory language was struck down as written. Further, the holding was understood to apply only to the rights of the successful litigant." $I d$. at 682.). For a qualified critique of the idea of facial challenges, see Richard H. Fallon, Jr., Commentary, As-Applied and Facial Challenges and Third-Party Standing, II 3 HARV. L. REV. I 32 I (2000). 
Second, there has been a change for some judges in their selfconception of what they are doing vis-à-vis an unconstitutional statute. The traditional conception is that a judge does not so much strike down an unconstitutional law as refuse to apply it. ${ }^{197}$ A judge has a duty to follow the law. ${ }^{198}$ Where there is a conflict among legal authorities, that duty compels the judge to follow the higher law. When a statute is "repugnant" 199 to the Constitution, that is, when a statute is inconsistent with the Constitution, a judge simply does not apply it. This view is represented by Marbury v. Madison. ${ }^{200}$

A different view is common today, and it can be found in the metaphorical language of courts and commentators. We speak of a statute, regulation, or order being "struck down," words that are physical and violent. $^{201}$ Such language has accompanied a shift in the idea of what courts do with an unconstitutional statute. Instead of seeing courts as preventing or remedying a specific wrong to a person and only incidentally determining the constitutionality of a law, ${ }^{202}$ now many see courts as determining the constitutionality of a law and only incidentally preventing or remedying a specific wrong to a person. ${ }^{203}$ For this view, too, appeal is made to Marbury. ${ }^{204}$

197 E.g., Carter v. Carter Coal Co., 298 U.S. 238, 296-97 (1936) (stating that a federal court, being "required to ascertain and apply the law to the facts in every case or proceeding properly brought for adjudication, must apply the supreme law and reject the inferior statute whenever the two conflict"); Howard v. Ml. Cent. R.R. Co. (The Employers' Liability Cases), 207 U.S. 463, 504 (I908) ("[W]e are of the opinion that the courts below rightly held the statute to be repugnant to the Constitution and non-enforcible ...."). See generally Mary Sarah Bilder, The Corporate Origins of Judicial Review, I 6 YALE L.J. 502 (2006); Harrison, supra note 194; Kevin C. Walsh, Partial Unconstitutionality, 85 N.Y.U. L. REV. 738 (2010).

198 See generally Philip Hamburger, LAW AND JUdicial DUty (2008).

199 Marbury v. Madison, 5 U.S. (I Cranch) 137, I 76 (I803).

200 See id. at I 78 (calling it "of the very essence of judicial duty," when a law and constitution conflict, to "determine which of these conflicting rules governs the case"); Bilder, supra note I97, at 560 ; Harrison, supra note I 94, at 85-86.

$201 C f$. LeONARD COHEN, I'm Your Man, on I'M Your MAN (Columbia Records I988) ("[I]f you want to strike me down in anger / Here I stand").

202 HART \& WECHSLER, supra note 96 , at 93.

203 Compare United States v. Raines, 362 U.S. I7, 2 I (1960) ("This Court, as is the case with all federal courts, 'has no jurisdiction to pronounce any statute, either of a State or of the United States, void, because irreconcilable with the Constitution, except as it is called upon to adjudge the legal rights of litigants in actual controversies." (quoting Liverpool, N.Y. \& Phila. S.S. Co. v. Comm'rs of Emigration, I I 3 U.S. 33, 39 (I 885))), and Muskrat v. United States, 2 I 9 U.S. 346, 36 I (I9II) ("The right to declare a law unconstitutional arises because an act of Congress relied upon by one or the other of such parties in determining their rights is in conflict with the fundamental law."), with Henry P. Monaghan, Constitutional Adjudication: The Who and When, 82 YALE L.J. I363, I3657 I (1973) (arguing that the Court has the "special function," id. at 1370 , to render judgments in constitutional litigation regardless of whether private rights are implicated).

204 See Monaghan, supra note 203, at 1370 ("Marbury itself provides the basis for a different model of judicial competence."). Professor Henry Monaghan charts the shifting reception: "In important part, Marbury found the power of constitutional exposition to be an incident of the Court's obligation to decide the particular 'case or controversy' before it. Thus, constitutional litigation 
That shift matters for the logic of the national injunction. If a court considers a statute inconsistent with the Constitution, and thus does not apply it, nothing follows about the remedy. The court has not done anything to the statute. It remains undisturbed. But on the newer conception of what a court does - striking down or setting aside an unconstitutional statute or unlawful regulation - a national injunction begins to have a relentless logic. ${ }^{205}$ If a court strikes down a statute, regulation, or order, why should it give it respect by allowing its continued enforcement? Wouldn't enforcement, anywhere, offend the court's determination that it was invalid, struck down, obliterated? If a law is unconstitutional in all its applications, ${ }^{206}$ why should the court permit it to be applied to anyone? Again, reasons can be given for stopping short ones grounded in equitable remedies, judicial competence, humility, separation of powers, federalism, and so on. But the logic of the national injunction is certainly strengthened by the newer view of what judges do when one law is inconsistent with a higher one, as well as by the metaphorical language used to express that view.

\section{Other Changes?}

In addition to these ideological shifts, there were other changes in the twentieth century that might have made the national injunction begin to seem natural. Three are considered here: statutes concentrating judicial power in a single court or circuit, greater use of rulemaking by federal agencies and pre-enforcement review of that rulemaking, and renewed judicial confidence after Brown v. Board of Education ${ }^{207}$ and Cooper $v$. Aaron. ${ }^{208}$ These changes may offer explanation and context

\footnotetext{
was viewed as essentially no different from any other adjudication." Id. at ${ }_{3} 6_{5}$ (footnote omitted). But, Monaghan adds, "the case is now taken to have established that the Court's constitutional interpretations are final and authoritative." $I d$.

205 See Fallon, supra note I 66 , at 1339 (making a similar point about the misleading implications of saying that courts "invalidat[e]" unconstitutional statutes); Hill, supra note 196 , at 683 ("Much confusion would be avoided if it were recognized that courts only adjudicate the rights of litigants, and are not in the business of killing or mutilating statutes."). An example is Justice Blackmun's dissent in Lujan v. National Wildlife Federation, 497 U.S. 87 I (I990). From the premise of what a judge does to an agency action - "the rule is invalidated" - Justice Blackmun moved quickly to the scope of the remedy: "Under these circumstances a single plaintiff, so long as he is injured by the rule, may obtain 'programmatic' relief that affects the rights of parties not before the court." Id. at $9 \mathbf{I}_{3}$ (Blackmun, J., dissenting). The majority's response was opaque. Id. at 890 n.2 (majority opinion); $c f$. Nat'l Mining Ass'n v. U.S. Army Corps of Eng'rs, I45 F.3d I 399, I409 (D.C. Cir. I998) (Williams, J.) (concluding that Justice Blackmun was "apparently expressing the view of all nine Justices on this question").

206 The conventional definition of facial challenges is that they are "ones seeking to have a statute declared unconstitutional in all possible applications," while all other challenges are considered asapplied. Richard H. Fallon, Jr., Fact and Fiction About Facial Challenges, 99 CALIF. L. REV. 9I5, 923 (2OII). Other definitions are possible, but the conventional one is used here.

207347 U.S. 483 (I954).

208358 U.S. I (1958).
} 
for the development of the national injunction, but none offers justification.

First, in the twentieth century, a number of statutes concentrated judicial review in a single court or circuit. ${ }^{209}$ It could be that these statutes led judges, lawyers, and scholars to think of a single court's decree as controlling the federal government's conduct against everyone. $^{210}$ Moreover, the consequences of national injunctions are much less dire if they are issued by a single court in which judicial review has been concentrated: no forum shopping, because the cases must be brought in that court; no lost percolation, because the choice has already been made against percolation with the one-court structure; and little risk of conflicting injunctions, because all of the injunctions will issue from the same court.

But the concentration of judicial review does not neatly explain the rise of the national injunction. Review of the orders of the Interstate Commerce Commission was concentrated in a single court from I 9 I I to I9 I3, long before there were national injunctions. ${ }^{211}$ The affirmance of a national injunction in Harlem Valley Transportation Association $v$. Stafford in I974 seems to have been the breakthrough in judicial practice, and it was the work of a generalist court. Nor do these statutes support an inference that federal district courts should now issue national injunctions. In fact, the reverse is true. Congress knows how to concentrate judicial review in a single court; when it has not chosen to do so, a district court should not act as if Congress had made that choice.

Another change that might have led to national injunctions was an increase in general rulemaking by federal agencies. A number of statutes enacted in the I 960 s and I970s authorized general rulemaking, such as the National Traffic and Motor Vehicle Safety Act, ${ }^{212}$ the Clean Air Act, ${ }^{213}$ and the Clean Water Act. ${ }^{214}$ At roughly the same time, Judge Wright and Judge Friendly offered revisionist statutory interpretations that gave several federal agencies legislative rulemaking. powers. ${ }^{215}$

209 David P. Currie \& Frank I. Goodman, Judicial Review of Federal Administrative Action: Quest for the Optimum Forum, 75 COLUM. L. REV. I, 62-63 (I975).

210 Similarly, Congress required certain kinds of cases to be heard by three-judge courts. See generally David P. Currie, The Three-Judge District Court in Constitutional Litigation, 32 U. CHI. L. REV. I (I964). For roughly the middle third of the twentieth century, a constitutional challenge to a federal statute was heard by a three-judge court, with a right of immediate appeal to the Supreme Court, under a statute adopted in response to the myriad injunctions against enforcement of New Deal statutes. See id. at Io-I I. Three-judge courts were abolished for most cases in I 976 . See Shapiro v. McManus, 136 S. Ct. 450, 453 (2015).

211 Currie \& Goodman, supra note 209 , at 62 .

212 Pub. L. No. $89-563,80$ Stat. 718 (I966) (codified at 49 U.S.C. $\$ \S 30101-30170$ (20I2)).

21342 U.S.C. $\$ \$ 7401-767$ Iq (20I2).

21433 U.S.C. $\$ \$ \mathrm{I} 25 \mathrm{I}-\mathrm{I} 387$ (20I2).

215 Thomas W. Merrill \& Kathryn Tongue Watts, Agency Rules with the Force of Law: The Original Convention, I 6 HARV. L. REV. 467, 546-70 (2002). 
Meanwhile, as federal rulemaking expanded, the Supreme Court revised its ripeness doctrines, making it easier to bring pre-enforcement challenges to agency action. ${ }^{216}$ And Congress joined in, encouraging preenforcement review of agency actions. ${ }^{217}$ The total effect was to markedly increase the number of pre-enforcement challenges.

Even so, it is not obvious that more rulemaking and more preenforcement challenges have any logical implication for the scope of injunctions. It does seem that agencies now act more often in a legislative mode, making general rules, rather than taking relatively specific actions such as setting rates for a railroad operating between Shreveport and Dallas. But before the shift to national injunctions, there were many statutes enacted by Congress. Those statutes could be challenged before enforcement, with the litigant seeking an antisuit injunction or what might be called an antisuit declaratory judgment. ${ }^{218}$ As already discussed, there were many such challenges to New Deal legislation. ${ }^{219}$ But there were no national injunctions. Thus there is no logical or practical inconsistency between (a) plaintiff-protective injunctions and (b) a large quantity of pre-enforcement challenges to generally applicable legal norms. ${ }^{20}$

Yet another change that might have influenced the development of the national injunction was the desegregation cases of the I950s and I 96os. The impact of Brown v. Board of Education and Cooper v. Aaron in dismantling Southern de jure segregation has been the subject of revisionist histories. ${ }^{221}$ As an idea, however, the influence of these cases

216 Professor Jerry Mashaw has described Abbott Laboratories $v$. Gardner, 387 U.S. I36 (I967), as the case that established the general proposition "that preenforcement review of rules in an appellate form is appropriate general practice." Jerry L. Mashaw, Rethinking Judicial Review of Administrative Action: A Nineteenth Century Perspective, 32 CARDOZO L. REV. 224I, 2252 \& n.43 (2OII).

217 See Paul R. Verkuil, Congressional Limitations on Judicial Review of Rules, 57 TUL. L. REV. $733,734-35$ (I 983 ).

218 See Emily Sherwin \& Samuel L. BRay, Ames, Chafee, ANd Re on Remedies (forthcoming 2017 ) (ch. To manuscript at $5 \mathrm{I}-52,55-56$ ); Harrison, supra note 187 , at 1000.

219 See supra pp. 433-35.

220 One way to distinguish challenges to agency rules from challenges to statutes might be the Administrative Procedure Act, and in particular its statement that a federal court should "hold unlawful and set aside" an invalid agency action. 5 U.S.C. $\$ 706(2)$ (2012) (emphasis added). Whatever view should be taken of that provision, compare Duffy, supra note $\mathbf{1}_{3}$, with Ronald M. Levin, "Vacation" at Sea: Judicial Remedies and Equitable Discretion in Administrative Law, 53 DUKE L.J. 29I (2003), it does not explain the national injunction, which would not be embraced by the federal courts until the I970s, nearly three decades after the passage of the Act. For further discussion, see supra note I 2 I.

221 See Gerald N. Rosenberg, The Hollow Hope: Can Courts Bring about SoCiAl Change? (2d ed. 2008); $c f$. MiChaEl J. Klarman, From Jim Crow to Civil Rights: THE SUPREME COURT AND THE STRUGGLE FOR RACIAL EQUALITY (2004). Moreover, much of the civil rights movement happened outside the courts. See TOMIKo Brown-NAGIN, COURAGE TO DisSENT. ATLANTA AND THE LONG History of THE Civil Rights MOVEMENT (20rI). 
is hard to overestimate. That idea includes not only the principle of racial equality, but also the fact that it was federal judges who declared that principle. The moral rightness of the desegregation cases seemingly reshaped federal judges' self-conception of their remedial role. After the Brown era, judges became more willing to give commands to federal and state officers. After the Brown era, those officers became more willing to follow the judges' commands.

Moreover, the desegregation decrees gave federal judges experience with broader injunctions. As Southern officials engaged in massive resistance to Brown, the personal cost of being a plaintiff was high. ${ }^{222}$ One solution was class actions; these may have encouraged judges to think of desegregation injunctions in systemic terms. Another solution was an injunction - in an individual suit - that went beyond the plaintiff and desegregated the entire school district. ${ }^{223}$ Indeed, by 1972 the following view could be expressed in the treatise on federal courts by Professors Charles Wright and Arthur Miller:

In most civil rights cases plaintiff seeks injunctive or declaratory relief that will halt a discriminatory employment practice or that will strike down a statute, rule, or ordinance on the ground that it is constitutionally offensive. Whether plaintiff proceeds as an individual or on a class suit basis, the requested relief generally will benefit not only the claimant but all other persons subject to the practice or the rule under attack. ${ }^{224}$

To be certain, the authority Wright and Miller cited for this proposition was thin. ${ }^{225}$ Still, some desegregation decrees did go beyond protecting the plaintiff.

222 See David Marcus, Flawed but Noble: Desegregation Litigation and Its Implications for the Modern Class Action, 63 FLA. L. REV. 657, 680 n.I 34 (201 I).

223 A series of cases held that for challenges to racial discrimination, the injunctive relief granted would be the same regardless of whether a class was certified. See, e.g., United Farmworkers of Fla. Hous. Project, Inc. v. City of Delray Beach, 493 F.2d 799, 8I 2 (5th Cir. I974) ("[R]acial discrimination is by definition class discrimination.").

2247 Charles Alan Wright \& ARthur R. Miller, Federal Practice \& Procedure

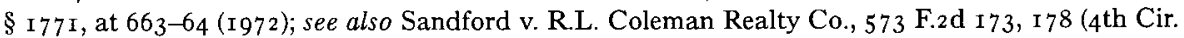
I978) (quoting the last sentence of the block quote from Wright and Miller and calling it "the settled rule"). For a contrary view from a commentator writing before Brown about desegregation cases, see Comment, The Class Action Device in Antisegregation Cases, 20 U. CHI. L. REV. 577,578 (I953).

225 Of the five cases cited by Wright and Miller, the oldest and most important was Bailey $v$. Patterson, 323 F.2d 201 (5th Cir. I963). Bailey was a transportation desegregation case challenging two Mississippi statutes and a Jackson, Mississippi, ordinance. It was decided almost a decade after Brown, and it had already been to the U.S. Supreme Court, which had remanded "for expeditious disposition." Bailey v. Patterson, 369 U.S. 3I, 34 (I962) (per curiam). On remand, the Fifth Circuit recognized that the U.S. Supreme Court "specifically noted that this is a class action," Bailey, $3_{2} 3$ F.2d at 2o6, yet the Fifth Circuit thought it "unnecessary to determine ... whether this action was properly brought under Rule 23 (a)." Id. Any injunction would have the same scope, the court said, because of the right at issue: "Appellants . . seek the right to use facilities which have been desegregated, that is, which are open to all persons, appellants and others, without regard to race. The very nature of the rights appellants seek to vindicate requires that the decree run to the benefit not only of appellants but also for all persons similarly situated." $I d$. Of the four other 
Yet there are also reasons to doubt that desegregation decrees led directly to national injunctions. The geographic scope of the injunctions, when they went beyond the plaintiffs, was usually the school district, not anything like the entire nation. An injunction against a school or a school district has a much firmer basis in traditional equity: it is easier to analogize such an injunction to the bill of peace, given its small scale, the preexisting social group, and the impersonal quality of the claims. ${ }^{226}$ Moreover, when courts gave these injunctions, the details of the particular school district's history of legal segregation mattered, a fact which is hard to square with a relatively coarse-grained national injunction.

Finally, there is the impact of the I 966 amendments to Rule 23 of the Federal Rules of Civil Procedure. Among the changes was the addition of the Rule 23(b)(2) class action - a class action for injunctive and declaratory relief that was especially meant for civil rights cases. ${ }^{227}$ There is something logically odd about Rule $23(\mathrm{~b})(2)$ leading to broader injunctions in non-class actions. One would have thought the implication was the reverse: because there was express authorization for class actions that could secure injunctive relief for a class of plaintiffs, there was less need for broad injunctions in non-class actions. Nevertheless it is at least possible that the practical effect of the 1966 amendments was to make judges more familiar with injunctions that protected a large class of plaintiffs, and then, more familiar with such injunctions, judges were willing to give them even in non-class actions.

Thus each of these additional explanations - statutes concentrating judicial review, the rise of general rulemaking, and judicial confidence - is insufficient on its own. Yet together they may have contributed to the conceptual shifts discussed above. A steady increase in general rules, and in pre-enforcement challenges to those rules, makes it easier for courts and litigants to think of challenges as "facial" instead of as fending off a threatened enforcement action. And a judiciary that got Brown right could be more self-assured and more willing to declaim on issues and not merely decide cases.

In short, the rise of the national injunction seems to have been gradual and unplanned. The best understanding of the evidence is that the national injunction went from being unthinkable to being thinkable

cases cited by Wright and Miller, three were class actions, Unemployed Workers Union v. Hackett, 332 F. Supp. 1372 (D.R.I. I97 I); Moss v. Lane Co., 50 F.R.D. I 2 (W.D. Va. I970); Snyder v. Bd. of Trs. of the Univ. of Ill., 286 F. Supp. 927 (N.D. Ill. 1968), and one was an individual action under Title VII, Gregory v. Litton Sys., Inc., 316 F. Supp. 40 I (C.D. Cal. 1970).

226 On the bill of peace, see supra notes $36-45$ and accompanying text. For suits to remedy racial discrimination, some courts and commentators emphasize the distinctive "group character of the underlying substantive claim." OWEN M. FISS, THE CIVIL RIGHTS INJUNCTION I5 (I978).

227 See generally Marcus, supra note 222. 
without any sharp turns or decisive moments. What made it thinkable was not a single unifying cause, ${ }^{228}$ but rather shifts in how judges thought about legal challenges and invalid laws, accompanied by changes in agency practice and new reasons for judicial confidence.

One implication of this account, contrary to the Principles of the Law of Aggregate Litigation recently published by the American Law Institute, is that there is nothing "indivisible" about an injunction restraining the enforcement of a statute, regulation, or order. ${ }^{229}$ Protecting nonparties with an injunction is a remedial choice. It is a relatively new choice, and like all remedial choices, it needs to be justified.

\section{THE CONSEQUENCES OF THE NATIONAL INJUNCTION}

The choice to give a national injunction is increasingly shaping the policies of the United States. This Part explores the consequences of the national injunction - in particular the temptation of forum shopping, the likely impact on judicial decisionmaking, the risk of conflicting injunctions, and the tension between the national injunction and other doctrines and practices.

\section{A. The Incentive to Forum Shop}

National injunctions have increasingly thwarted the policies of the Federal Executive. When George W. Bush was President, national injunctions against the Administration's regulatory initiatives were issued by district court judges in California. For example, the Sierra Club and other plaintiffs challenged Bush Administration Forest Service regulations in Earth Island Institute v. Pengilly. ${ }^{230}$ The district court held several of the regulations invalid, enjoining their operation. ${ }^{231}$ After separate briefing directly on the scope of the court's order, the court insisted on giving a national injunction. ${ }^{232}$ "The appropriate remedy," the court concluded, "is to prevent such injury from occurring again by the operation of the invalidated regulations, be it in the Eastern District of California, another district within the Ninth Circuit, or anywhere else

228 Cf. JACQues BARzUn, The Fallacy of the Single Cause, in The Culture We Deserve I29, 132-33 (Arthur Krystal ed., I 989) (noting, with respect to historical developments, the recurrent "urge to find the single cause," $i d$. at 133 ).

229 Contra PRINCIPLES OF THE LAW OF AgGREgate Litigation, supra note $22, \$ 2.04 \mathrm{cmt}$. a, at I I-I9; Walker, supra note 6, at II4I ("If a plaintiff successfully challenges a rule of 'broad applicability,' then the relief, the invalidation of the rule, will naturally extend to persons beyond the named plaintiffs.").

230376 F. Supp. 2 d 994 (E.D. Cal. 2005).

231 Id. at Ior I; Earth Island Inst. v. Ruthenbeck, No. CIV F-03-6386, 2005 WL 5280466, at *I2 (E.D. Cal. Sept. 20, 2005) (discussing scope of injunction on motion to clarify and amend).

232 For another national injunction, see California ex rel. Lockyer $v$. United States Department of Agriculture, 468 F. Supp. 2d II4O, II42-44 (N.D. Cal. 2006). 
in the nation."233 The Ninth Circuit upheld the district court's national injunction, and it went even further, concluding that once the district court had found the regulations invalid, a national injunction was actually "compelled by the text of the Administrative Procedure Act," 234 because the Act requires a court to "hold unlawful and set aside agency action" found to be invalid. ${ }^{235}$

Near the end of the Obama Administration, national injunctions stymied many of the President's policies. Most prominent was the injunction in Texas v. United States, a case brought by Texas and a number of other states to challenge an immigration program, "Deferred Action for Parents of Americans and Lawful Permanent Residents," which gave lawful presence to millions of aliens for various federal-law purposes. ${ }^{236}$ The district court concluded that the program was likely a violation of the Administrative Procedure Act. ${ }^{237}$ The district court also concluded that a preliminary injunction should be issued halting the implementation of the program. ${ }^{238}$ But what would be the scope of that remedy? The court enjoined implementation for everyone, not just with respect to the twenty-six states that were plaintiffs. ${ }^{239}$ That preliminary injunction was affirmed by the Fifth Circuit, and by an evenly divided U.S. Supreme Court. ${ }^{240}$

Texas $v$. United States was not a unique challenge to the policies of the Obama Administration. In 2016, a district court judge issued a national preliminary injunction against a major Department of Labor regulation, the "persuader rule." 241 Another issued a national preliminary injunction regarding a "Dear Colleague" letter from the Department of Education about the statutory term "sex" and public school restrooms. ${ }^{242}$ Another issued a preliminary injunction against enforcement of a regulation requiring federal contractors to report labor violations. ${ }^{243}$ Another issued a national preliminary injunction against the enforcement

\footnotetext{
233 Earth Island Inst., 2005 WL 5280466 , at *2.

234 Earth Island Inst. v. Ruthenbeck, 490 F.3d 687, 699 (9th Cir. 2007).

235 Id. (some emphasis omitted) (quoting 5 U.S.C. $\$ 706(2)$ (2012)), rev'd on other grounds sub nom. Summers v. Earth Island Inst., 555 U.S. 488, 50I (2009) (declining to reach the question whether "a nationwide injunction would be appropriate"). On the APA argument, see supra note I 2 I.

236 Texas v. United States, 86 F. Supp. 3d 59r, 604 (S.D. Tex.), aff'd, 809 F.3d I34 (5th Cir. 2015), aff'd by an equally divided Court, I36 S. Ct. 227 I (2016) (mem.).

237 Id. at $67 x$

238 Id. at 676 .

239 See id.

240 Texas v. United States, 809 F.3d I 34 ( 5 th Cir. 20I5), aff'd by an equally divided Court, I $36 \mathrm{~S}$. Ct. 227 I (2016) (mem.).

241 Nat'l Fed'n of Indep. Bus. v. Perez, No. 5:I6-cv--0066, 2016 WL 3766I2 I, at *46 (N.D. Tex. June 27,2016 ).

242 Texas v. United States, 20I F. Supp. 3d 8Io, 835-36 (N.D. Tex. 2016).

243 Associated Builders \& Contractors of Se. Tex. v. Rung, No. I:I6-CV-425, 2016 WL 8I88655, at * ${ }_{5}$ (E.D. Tex. Oct. 24, 2016).
} 
of a Department of Labor regulation that would have made about four million workers eligible for overtime pay. ${ }^{244}$ Still another issued a national preliminary injunction against a rule interpreting an antidiscrimination provision in the Affordable Care Act (ACA). ${ }^{245}$ These national injunctions were all issued against a Democratic administration by federal district court judges in Texas. ${ }^{246}$

At the start of the Trump Administration, the President's executive order restricting entry to the United States from seven countries was blocked by a federal district judge in the State of Washington, who issued a national preliminary injunction. ${ }^{247}$ Other district judges also issued national preliminary injunctions against the original or later versions of the order. ${ }^{248}$ Another district court issued a national preliminary injunction against an executive order on "sanctuary cities." 249 In another challenge to the Administration's policies on "sanctuary cities," a district court issued a national preliminary injunction against grant conditions imposed by the Attorney General. ${ }^{250}$ In another case, involving representation in immigration proceedings, a district court blocked the enforcement of a cease-and-desist order with a national preliminary injunction. $^{251}$ All these national injunctions came in the first eight months of the Trump Administration.

It is no accident which courts have given the major national injunctions in the last three administrations. In the George W. Bush Administration, it was federal courts in California. In the Obama

244 Nevada v. U.S. Dep't of Labor, 2 I 8 F. Supp. 3d 520, 533-34 (E.D. Tex. 20I6).

245 Franciscan All., Inc. v. Burwell, 227 F. Supp. 3d 660, 695 (N.D. Tex. 2016).

246 In addition, a Sixth Circuit stay of the Clean Water Rule, which was adopted in 2015 by the Environmental Protection Agency, was in effect a national preliminary injunction. See In re EPA, 803 F.3 804 , 808-09 (6th Cir. 20I5).

247 Washington v. Trump, No. CI 7 -OI 41 , 2017 WL 462040 (W.D. Wash. Feb. 3, 20I7). The district court gave a temporary restraining order that was treated by the Ninth Circuit as an appealable preliminary injunction. Washington v. Trump, 847 F.3d I I 5 I, I I 58 (9th Cir. 2017) (per curiam).

248 Hawaii v. Trump, No. I 7-00050, 2017 WL 4639560, at * I 4 (D. Haw. Oct. I 7 , 20r 7 ) (granting temporary restraining order), appeal docketed, No. I 7-I 7 I 68 (9th Cir. Oct. 24, 20I 7); Int'l Refugee Assistance Project v. Trump, No. I 7-036I, 2017 WL 46743I4, at *40-4I (D. Md. Oct. I 7, 20I 7 ); Int'l Refugee Assistance Project v. Trump, 24I F. Supp. 3d 529, 566 (D. Md. 20I 7), aff'd in part, vacated in part, 857 F.3d 554 (4th Cir.), vacated and remanded, 2017 WL 4518553 (U.S. Oct. Io, 20I 7 ) (mem.) (per curiam); Hawai'i v. Trump, 245 F. Supp. 3d I 227 , I237-39 (D. Haw. 201 7), aff'd in part, vacated in part, 859 F.3d 741 (9th Cir.), vacated and remanded, 85 U.S.L.W. 3 I99 (U.S. Oct. 24, 2017 ) (No. I6-I 540); Darweesh v. Trump, I 7 Civ. 480, 2017 WL 388504, at *I (E.D.N.Y. Jan. 28, 2017 ).

249 County of Santa Clara v. Trump, 250 F. Supp. 3d 497, 539 (N.D. Cal. 20I 7 ).

250 City of Chicago v. Sessions, No. I 7 C 5720,2017 WL 408 I82 I, at * I4 (N.D. Ill. Sept. 15, 201 7 ) ("This injunction against imposition of the notice and access conditions is nationwide in scope, there being no reason to think that the legal issues present in this case are restricted to Chicago or that the statutory authority given to the Attorney General would differ in another jurisdiction."); see also City of Chicago v. Sessions, No. I7 C 5720, 20I7 WL 4572208 (N.D. Ill. Oct. I3, 201 7 ) (denying stay of national injunction).

251 Nw. Immigrant Rights Project v. Sessions, No. CI7-716, 2017 WL 3189032, at *6-7 (W.D. Wash. July 27, 2017). 
Administration, it was federal courts in Texas. Now, in the Trump Administration, the national preliminary injunctions have come from federal courts in several less conservative circuits (the Fourth, Seventh, and Ninth). The forum selection happens not only for the district court, but also for the appellate court. ${ }^{252}$ The pattern is as obvious as it is disconcerting. Given the sweeping power of the individual judge to issue a national injunction, and the plaintiff's ability to select a forum, it is unsurprising that there would be rampant forum shopping. ${ }^{253}$

The opportunity for forum shopping is extended by the asymmetric effect of decisions upholding and invalidating a statute, regulation, or order. ${ }^{254}$ If a plaintiff brings an individual action seeking a national injunction, and the district judge upholds the challenged law, that decision has no effect on other potential plaintiffs. But if one district judge invalidates it and issues a national injunction, the injunction controls the defendant's actions with respect to everyone. Shop 'til the statute drops.

Moreover, the potential effect of forum shopping for national injunctions is even greater than in the cases already described. Consider as well the cases in which district courts did not grant national injunctions but could have, including the challenge to the ACA that eventually led to the U.S. Supreme Court decision in National Federation of Independent Business v. Sebelius. ${ }^{255}$ A federal district court judge in Florida held the individual mandate unconstitutional, and also held that it could not be severed. ${ }^{256}$ Having thus decided that the entire statute was unconstitutional, the district court could have enjoined its enforcement. Indeed, the twenty-six plaintiff states requested an injunction, and the court could easily have concluded that enforcement of the statute should be enjoined

\footnotetext{
252 Note that if national injunctions were curtailed, there could still be forum shopping in individual cases, as plaintiffs make use of the broad venue provisions for suits against the federal government. See Kate Huddleston, Nationwide Injunctions: Venue Considerations, 127 YALE L.J.F. 242, 246-49 (2017).

253 What does not seem to have happened yet, but may be the next development, is that potential defendants would bring declaratory judgment actions or seek antisuit injunctions in order to do their own forum shopping.

254 Other scholars have noted this asymmetry. See Carroll, supra note 6, at 2020-2 I; Morley, De Facto Class Actions?, supra note 6, at 494 (calling it "asymmetric claim preclusion," though technically the effect is derived from the injunction and not the preclusive effect of the judgment); see also Andrew D. Bradt \& Zachary D. Clopton, $M D L$ v. Trump, I 12 NW. L. REV. (forthcoming 20I8) (evaluating, and ultimately rejecting, a possible solution to the forum-shopping problem, namely, consolidation under the Multidistrict Litigation Act), https://ssrn.com/abstract=3014825 [https://perma.cc/PJ7E-D2DB].

255567 U.S. 5 I9 (2012).

256 Florida $e x \mathrm{rel}$. Bondi v. U.S. Dep't of Health and Human Servs., 780 F. Supp. 2d 1256, I306 (N.D. Fla.), order clarified, 780 F. Supp. $2 \mathrm{~d}$ I 307 (N.D. Fla.), aff'd in part, rev'd in part sub nom. Florida ex rel. Att'y Gen. v. U.S. Dep't of Health and Human Servs., 648 F.3d I 235 (I Ith Cir. 201 I), aff'd in part, rev'd in part sub nom. Nat'l Fed'n of Indep. Bus. v. Sebelius, 567 U.S. 5 I9 (2012).
} 
throughout the country. ${ }^{257}$ Moreover, the court could have been concerned about evasion of its injunction, and thus further enjoined the Department of Health and Human Services (HHS) from spending money or allocating employees to work on plans for carrying out the putatively unconstitutional statute. Holding constant the pace of subsequent appeals, HHS would have lost seven and a half irreplaceable months for preparing to roll out the regulations for the statute. But the district court judge did not enjoin HHS. Instead he granted a declaratory judgment, and he subsequently stayed the judgment until appeals were exhausted. ${ }^{258}$ These were acts of judicial self-restraint, not judicial necessity. It is far from clear, given the district court's holding, that it would have been an abuse of discretion to enjoin all preparation for enforcement of the ACA. 259

\section{B. The Effect on Judicial Decisionmaking}

National injunctions interfere with good decisionmaking by the federal judiciary. When a district court grants a national injunction, that choice affects the Supreme Court's resolution of a legal issue.

The district court's injunction may halt federal enforcement everywhere. There may be no opportunity, then, for more circuits to express their views, because parties in other circuits might no longer bring their own challenges to the statute, regulation, or order. The Supreme Court is thus more likely to hear a case without the benefit of disagreement from the courts of appeals. It is denied what Judge Leventhal famously described as the "value in percolation among the circuits, with room for a healthful difference that may balance the final result." 260

Moreover, the Court's resolution may be accelerated and relatively fact-free. If the district court's national injunction is issued before trial,

257 The Second Amended Complaint requested injunctive relief, but only as to enforcement against the twenty-six plaintiff states and their citizens, residents, and officers. Second Amended Complaint at 4, Bondi, 780 F. Supp. 2 d I 256 (No. 3: IO-cv-9I).

258 Bondi, 780 F. Supp. $2 \mathrm{~d}$ at I307; Bondi, 780 F. Supp. $2 \mathrm{~d}$ at 1320 . That declaratory judgment was later the subject of a confused motion to clarify filed by the Department of Justice, as discussed in Bray, supra note 143 , at $1092-93$.

259 Nor is it clear that the solution would have been stays of the injunction from the court of appeals or the Supreme Court. The court of appeals agreed with the district court's decision about the invalidity of the individual mandate, and even though in time it would find that provision severable, it is not at all certain that it would have found an injunction to be an abuse of discretion. In the Supreme Court, it is also not clear that there were five votes in $201 \mathrm{I}$ to uphold the statute. A majority of the Supreme Court might have declined to stay an injunction against the ACA, and then that provisional commitment by five Justices might have led to the Court striking down the individual mandate on the merits the following year. The psychological premise is simple: once a Justice makes a decision about a preliminary injunction, it will be hard to reverse course on the merits. See sources cited infra note 263 .

260 Harold Leventhal, A Modest Proposalfor a Multi-Circuit Court of Appeals, 24 AM. U. L. REV. 88 I, 907 (I975). 
and the defendant appeals to the Supreme Court for a stay of the preliminary injunction, then the Supreme Court's decision will take place without a record. ${ }^{261}$ It is true that the Court, in deciding a motion to stay a preliminary injunction, is usually not deciding the merits, only whether the plaintiff is likely to prevail on the merits. ${ }^{262}$ But it is natural for a judge, like any other human being, having once accepted a position, to stick to it. ${ }^{263}$

In a legal system that emphasizes the development of law through cases and through distributed decisionmaking, it would be unfortunate if the Court began to decide major constitutional questions not in order to resolve circuit splits but instead to address stays of district court preliminary injunctions. Indeed, that might have happened in National Federation of Independent Business $v$. Sebelius if the district court had behaved differently; ${ }^{264}$ it very nearly happened in Texas $v$. United States $^{265}$ and Washington $v$. Trump. ${ }^{266}$ A world of national injunctions is one in which the Supreme Court will tend to decide important questions more quickly, with fewer facts, and without the benefit of contrary opinions by lower courts.

\section{The Risk of Conflicting Injunctions}

The forum shopping and decisionmaking effects of the national injunction can obscure a less common but also potentially serious problem, namely, conflicting injunctions. The most colorful example involves the battle for the control of the Erie Railroad in the late nineteenth century. There were repeated instances of conflicting injunctions, as multiple judges wielding equitable powers would give diverging commands to litigants, one judge mandating the sale of stock and another judge prohibiting it. ${ }^{267}$

Nor are all the examples historical. At the very end of the Obama Administration, two lawsuits were filed by immigrants not legally in the United States challenging the scope of the district court injunction in

261 See Dan B. Dobbs, Should Security Be Required as a Pre-Condition to Provisional Injunctive Relief?, 52 N.C. L. REV. IOgI, IIII (1974) ("Procedure in provisional relief cases, far from providing a rational process for development of, and reflection upon, law and fact, forces immediate decisions without the light of fact or the delineation of policy.").

262 In some cases an appellate court even renders a final judgment while reviewing a preliminary injunction. See LAYCOCK, supra note 6, at 469 .

263 See In re Opinion of the Justices, 69 A. 627,63I (Me. I 908) (opinion of Savage, J.) (recognizing that an advisory opinion would not bind the Justices in a subsequent case, and adding: "Nevertheless it is my belief that, while human and judicial nature remain as we know them to be, the opinion of the justices will quite likely be the judgment of the court."); $c f$. Jean O. Lanjouw \& Josh Lerner, Tilting the Table? The Use of Preliminary Injunctions, 44 J.L. \& ECON. 573, 587 (2001).

264 See supra note 259 and accompanying text.

265 See supra notes $236-40$ and accompanying text.

266 See supra note 247 and accompanying text.

267 Adams, supra note 183 , at 22-99. 
Texas $v$. United States. ${ }^{268}$ The plaintiffs in these two suits, one of which was filed in the Eastern District of New York ${ }^{269}$ and one in the Northern District of Illinois, ${ }^{270}$ sought declaratory judgments that the Texas injunction did not apply in New York and Illinois, respectively. ${ }^{271}$ The plaintiffs also sought injunctions requiring the federal government to ignore the Texas injunction in their own cases. ${ }^{272}$ In the New York case, the judge even signaled his willingness to accept the plaintiff's argument, hinting that he might order the federal defendants to disregard the injunction from the district court in Texas. ${ }^{273}$ If that had happened, it might have been Erie Railroad all over again.

In less dramatic cases there have also been conflicting injunctions issued to the same parties. Typically one judge or the other backs down, narrowing or staying one of the issued injunctions, or else an appellate court reverses one of them. ${ }^{274}$ But those decisions are exercises of selfrestraint. The risk of conflicting injunctions is still there, lurking in the

268 Daniel Denvir, New Hope for Undocumented Immigrants: DAPA Might Not Be Dead - A Bold Legal Strategy Could Protect Millions from Deportation, SALON (Oct. I3, 2016, 10:00 AM), http://www.salon.com/2016/10/1 3/new-hope-for-undocumented-immigrants-dapa-might-not-be-deada-bold-legal-strategy-could-protect-millions-from-deportation/ [https://perma.cc/Q6LQ-ARWJ].

269 Complaint, Batalla Vidal v. Baran, No. I:I6-cv-04756 (E.D.N.Y. Aug. 25, 2016).

270 Complaint, Lopez v. Richardson, No. I:I6-cv-09670 (N.D. Ill. Oct. I2, 2016).

271 Complaint, supra note 269 , at 15 ; Complaint, supra note 270 , at 18 .

272 Complaint, supra note 269 , at $\mathrm{I}_{5}$; Complaint, supra note 270 , at $\mathrm{I} 8$.

273 One reporter wrote at the time:

Judge Garaufis seems inclined to Vidal's argument. In a pre-motion conference in late September, he announced that he had "absolutely no intention of simply marching behind in the parade that's going on out there in Texas, if this person has rights here."

"I sympathize with your problem," he told the government, "but I do not sympathize with the idea that I am hamstrung in dealing with an issue involving individual rights and including the right to go make a living and have a life as an immigrant in the United States." How, he asked, could a judge in one jurisdiction "issue a nationwide injunction if someone comes to him with a claim that affects the rights of people in" another jurisdiction "who have not been before the court?"

Denvir, supra note 268.

274 See, e.g., Feller v. Brock, 802 F.2d 722, 727-28 (4th Cir. I986) (vacating a preliminary injunction that directly conflicted with another court's injunction, on the grounds that the injunction under review failed to preserve the status quo, failed to correctly apply the balance of hardships doctrine, and disserved the public interest); California ex rel. Lockyer v. U.S. Dep't of Agric., 7 IO F. Supp. 2d 9I6, 92 I-24 (N.D. Cal. 2008) (partially staying an injunction that reinstated an agency rule, in order to reduce the conflict with a subsequently issued injunction by another federal district court that forbade the use of the rule); see also Colby v. J.C. Penney Co., 8I I F.2d I I I9, I I24 (7th Cir. I987) ("Where different outcomes would place the defendant under inconsistent legal duties, the case for the second court's not going into conflict with the first is particularly strong."); Nat'l Union Fire Ins. Co. of Pittsburgh, Pa. v. Payless ShoeSource, Inc., No. C-II-I892, 2012 WL 3277222 , at $* 9$ n.4 (N.D. Cal. Aug. 9, 2012) (declining to issue an injunction against litigation in another federal district court out of concern, perhaps misplaced, that "conflicting injunctions [could] make compliance with both an impossibility for the parties affected"). 
background, and perhaps it will move quickly to the foreground. Conflicting injunctions can be avoided with judicial restraint and good luck, but neither one is sure to last forever. ${ }^{275}$

\section{The Doctrinal Inconsistencies}

There are a number of doctrines and patterns of judicial decisionmaking that are premised on the absence of national injunctions. The availability of national injunctions allows a plaintiff suing a federal defendant to make an end run around these doctrines and patterns. Briefly consider four examples:

First, the doctrine of nonmutual offensive issue preclusion does not apply against the federal government. ${ }^{276}$ That exception to ordinary preclusion rules is meaningful as long as the remedy in a particular case protects only the plaintiffs. But if national injunctions were to become the norm, this doctrine would be vestigial. ${ }^{277}$

Second, Rule $23($ b)(2) makes a class-wide injunctive remedy available if certain conditions are met; ${ }^{278}$ the implication is that the remedy is available only if those conditions are met. Nevertheless, the need for and value of this class action provision is greatly diminished if plaintiffs

275 Charles F. Adams, Jr., made exactly this point about the Erie Railroad litigation:

Such a system can, in fact, be sustained only so long as co-ordinate judges use the delicate powers of equity with a careful regard to private rights and the dignity of the law, and therefore, more than any which has ever been devised, it calls for a high average of learning, dignity, and personal character in the occupants of the bench. When, therefore, the ermine of the judge is flung into the kennel of party politics and becomes a part of the spoils of political victory; when by any chance partisanship, brutality, and corruption become the qualities which especially recommend the successful aspirant to judicial honors, then the system described will be found to furnish peculiar facilities for the display of these characteristics.

Adams, supra note 183 , at 23 .

276 United States v. Mendoza, 464 U.S. I54, I 58 (I984). "Offensive non-mutual collateral estoppel is a version of the doctrine that arises when a plaintiff seeks to estop a defendant from relitigating an issue which the defendant previously litigated and lost against another plaintiff." Appling $v$. State Farm Mut. Auto. Ins. Co., 340 F.3d 769, 775 (9th Cir. 2003) (emphasis added) (citing Parklane Hosiery Co. v. Shore, 439 U.S. 322, 329 (1979)).

277 When issuing a national injunction, some courts explicitly distinguish Mendoza as pertaining to preclusion, not injunctions. See, e.g., California ex rel. Lockyer v. U.S. Dep't of Agric., 468 F. Supp. 2d Ir 4 o, I I 44 (N.D. Cal. 2006); cf. Nat'l Mining Ass'n v. U.S. Army Corps of Eng'rs, I 45 F.3d 1399, I409-10 (D.C. Cir. I998) (recognizing that national injunctions "diminish[] the scope of the $[$ Mendoza $]$ doctrine, under which the government may normally relitigate issues in multiple circuits," id. at $\mathbf{1} 409$, but affirming one anyway). But see Va. Soc'y for Human Life, Inc. v. FEC, ${ }_{26} \mathrm{~F}_{3}$ d 379, 392-94 (4th Cir. 200I) (rejecting a national injunction in part because of the concerns raised in Mendoza).

278 FED. R. CrV. P. 23 (b)(2) (allowing class actions, assuming other requirements are met, if "the party opposing the class has acted or refused to act on grounds that apply generally to the class, so that final injunctive relief or corresponding declaratory relief is appropriate respecting the class as a whole"). On the background of the provision, see Marcus, supra note 222. 
can get the same relief in an individual suit that they can in a class action. ${ }^{279}$

Third, there is the power of plaintiffs to initiate contempt proceedings. When a defendant violates an injunction, the plaintiff who succeeded in getting the injunction can try to enforce it with contempt. 280 That rule is well suited to injunctions that protect only the plaintiff. But it sits uneasily with injunctions that control the behavior of the defendant toward nonparties. Nonparties cannot initiate civil contempt proceedings to enforce the injunction. ${ }^{281}$

Fourth, there are limitations on the power of a federal district court to establish precedent. A federal district judge's decision does not bind other district courts. ${ }^{282}$ Indeed, it is not even an authoritative precedent for other judges in the same district court. ${ }^{283}$ Nor can a federal district court decision assure "clearly established law" for purposes of qualified immunity. ${ }^{284}$ Given these limitations on a federal district judge's authority to recognize and determine the law for anyone but the parties, it would be strange if a district judge could do so by means of a national injunction. ${ }^{285}$

\section{The FAILuRE OF EXISTING LIMITS}

Judicial decisions on when an injunction should be issued are recognized by scholars to be a muddle of inconsistent generalizations. There are relevant principles, but they are indeterminate and inconsistent with one another. ${ }^{286}$ The permissibility of injunctions protecting nonparties

\footnotetext{
279 Cf. John Bronsteen \& Owen Fiss, The Class Action Rule, 78 NoTrE DaME L. Rev. I4I9, 1433-34 (2003). In some cases the decision to bring a suit as a class action under Rule 23(b)(2) will prevent its being moot, and the certification of a class can increase the number of plaintiffs who are empowered to enforce the injunction. Carroll, supra note 6, at $2036,2038$.

280 Contempt proceedings may also be initiated by the court or a federal prosecutor.

281 Gompers v. Buck's Stove \& Range Co., 22 I U.S. 4I 8, 444-45 (I9II) ("Proceedings for civil contempt are between the original parties ...."); Carroll, supra note 6, at 2038 ("[A] defendant in an individual case might refuse to apply a system-wide remedy to anyone other than the plaintiff; under those circumstances, the other potential claimants (as nonparties) would have no power to enforce the injunction or declaration."); see also Ahearn ex rel. NLRB v. Int'l Longshore \& Warehouse Union, Locals 2 I \& 4, 72 I F.3d I I 2, I I3I-32 (gth Cir. 20I3) (reversing award of compensatory civil contempt to nonparties while raising qualifications to the general rule).

282 Fallon, supra note 196 , at 1340 (noting that "even if the district court purported to hold the statute invalid on its face, its holding would not bind other federal district courts in cases involving other parties").

283 Threadgill v. Armstrong World Indus., Inc., 928 F.2d I366, I37 I (3d Cir. I 991).

284 See Jack M. Beermann, Qualified Immunity and Constitutional Avoidance, 2009 SUP. CT. REV. I39, I60.

285 Another weakness of a geographic solution, see supra note $\mathrm{I} 9$, is that it would dramatically increase the power of a federal district court to determine the law within a circuit.

286 Carroll, supra note 6, at 2033 ("In light of the variations and inconsistencies in the case law . . . a plaintiff will likely be able to find authority supporting a grant of system-wide relief in a
} 
has never been squarely addressed by the Supreme Court. ${ }^{287}$ Among lower court decisions, to the extent there is a theme, it is that federal trial courts have broad discretion to award national injunctions whenever they seem warranted. A trial court's decision to issue (or not issue) a national injunction is then reviewed on appeal for abuse of discretion. ${ }^{288}$

To be sure, the cases do have apparent constraints on the granting of national injunctions. The one most commonly raised by courts and commentators is the principle of "complete relief," which is that "injunctive relief should be no more burdensome to the defendant than necessary to provide complete relief to the plaintiffs." ${ }^{289}$ This principle suggests that when a national injunction is needed for complete relief a court should award one, and when it is not needed for complete relief a court should not award one. It is thus two sided, by turns a shield for defendants and a sword for plaintiffs, depending on the case. ${ }^{290}$ The complete-relief principle is intuitively appealing, and it suits the most basic aim of the law of remedies: to put the plaintiff in her rightful position. ${ }^{291}$

Nevertheless, despite its acceptance by courts and commentators, the complete-relief principle is problematic. Complete relief is useful as an aim. But it fails as a legal principle intended to have outcomedeterminative force. This conclusion is supported by three reasons.

non-class case, and a defendant will likely be able to find authority opposing it. The same will be true of the district and appellate courts.").

287 The Court reserved the question in Summers v. Earth Island Institute, 555 U.S. 488, 500-0I (2009). Some cases, such as Lewis v. Casey, 5 I 8 U.S. 343 (I996), and Horne v. Flores, 557 U.S. 433 (2009), are suggestive about the need to match the remedy to the plaintiff's harm, but they do not squarely address the national injunction. On Horne $v$. Flores, see infra note $30 \mathrm{r}$.

288 See, e.g., Texas v. United States, 809 F.3d I34, 146 (5th Cir. 2015) (reviewing national preliminary injunction for abuse of discretion), aff'd by an equally divided Court, I36 S. Ct. 227I (2016) (mem.).

289 Califano v. Yamasaki, 442 U.S. 682, 702 (1979); see LAYCOCK, supra note 6, at 275-76; Morley, De Facto Class Actions?, supra note 6, at 5 IO. But cf. Walker, supra note 6, at II $35-37$ (noting that Califano was a class action, and thus not entirely on point for the scope of injunctions in nonclass cases). Although Califano attributes this statement to one of the litigants, 442 U.S. at 702 , it has been widely accepted as an endorsement by the Court. For further invocation of "complete relief" as a principle for the scope of an injunction, see, for example, Lewis, 5 I 8 U.S. at 3596o; Los Angeles Haven Hospice, Inc. v. Sebelius, 638 F.3d 644, 664 (9th Cir. 201 I); United States v. AMC Entertainment, Inc., 549 F.3d 760, 775 (9th Cir. 2008) (Wardlaw, J., dissenting in part); and Meinhold $v$. United States Department of Defense, 34 F.3d I469, I480 (9th Cir. I994). Zayn Siddique argues that the muddled and inconsistent decisions could be resolved if courts would "expressly adopt[] the requirement that a nationwide injunction should not issue unless it is necessary to provide complete relief to the plaintiffs." Siddique, supra note 6 (manuscript at 40 ).

290 Cf. Carroll, supra note 6, at 203 I \& n.7 I (noting this two-sided quality for the idea that the remedy "should be commensurate with the scope of the violation," $i d$. at $203 \mathrm{I}$ ).

291 LAYCOCK, supra note 6, at I4-I5; see Lewis, 5 I 8 U.S. at 358 (finding the harm to a "plaintiff in this lawsuit," rather than to other people, to be "the proper object of this District Court's remediation"); Frothingham, 262 U.S. 447, 488-89 (1923). 
First, although complete relief is ostensibly a limiting principle, the idea actually contributes to the general availability of the national injunction. What counts as complete relief will often be indeterminate, as even supporters of this principle acknowledge. ${ }^{292}$ To get past this indeterminacy, a frequent move in judicial opinions is to look to the "extent of the violation." 293 That inquiry seems innocuous, for it is a truism that the remedy should match the violation. ${ }^{294}$

But the move is actually consequential; it drains the complete-relief principle of any limiting power. The question of whether to issue a national injunction arises precisely because the extent of the violation the unconstitutional statute or the unlawful regulation or executive order - is national. The extent of the violation is national and so (courts reason) to give complete relief the injunction should also be national. ${ }^{295}$ In this way, the complete-relief principle can be taken by courts as a constraint on national injunctions or an impetus to give them, which is to say that it is no constraint at all. ${ }^{296}$

Second, by the point in time at which the court decides what might be needed for complete relief, there is already a tilt to the analysis. An injunction is often drafted in the first instance by the prevailing party, and though it should be scrutinized and revised by the judge, in this

\footnotetext{
292 See Siddique, supra note 6 (manuscript at 42 ).

293 AMC Entertainment, 549 F.3d at 775 (Wardlaw, J., dissenting in part) (quoting Califano, 442 U.S. at 702); see also, e.g., id. ("[D]istrict courts within our circuit commonly issue nationwide injunctions where the injunction ... is tailored to the violation of law that the Court already found - an injunction that is no broader but also no narrower than necessary to remedy the violations." (second alteration in original) (quoting California ex rel. Lockyer v. U.S. Dep't of Agric., 468 F. Supp. 2d II40, II 44 (N.D. Cal. 2006))); City of Chicago v. Sessions, No. I 7 C 5720 , 20I 7 WL 4572208 , at ${ }^{I-2},{ }^{*} 4$ (N.D. Ml. Oct. $\mathrm{r}_{3}, 2017$ ); Texas v. United States, 201 F. Supp. 3d 810, 836 (N.D. Tex. 20I6); Nat'l Fed'n of Indep. Bus. v. Perez, No. 5: 16-CV-00066, 20I6 WL 3766 I 2 I, at * 46 (N.D. Tex. June 27, 2016); Davis v. Astrue, 874 F. Supp. 2d 856, 868-69 (N.D. Cal. 2012). The same consideration is invoked in cases involving injunctions against state officers that run beyond the parties. See, e.g., Clement v. Cal. Dep't of Corr., 364 F.3d I I48, I I52-54 (9th Cir. 2004).

294 See Swann v. Charlotte-Mecklenburg Bd. of Educ., 402 U.S. I, 16 (I97 r) ("As with any equity case, the nature of the violation determines the scope of the remedy."). On the human impulse behind that doctrinal norm, see generally WILLIAM IAN MILLER, EYE FOR AN EYE (2006).

295 E.g., City of Chicago, 20I 7 WL 4572208 , at *2; Int'l Refugee Assistance Project v. Trump, 24 I F. Supp. 3d 529, 566 (D. Md. 2017) ("Here, nationwide relief is appropriate because this case involves an alleged violation of the Establishment Clause by the federal government manifested in immigration policy with nationwide effect."), aff'd in part, vacated in part, 857 F.3d 554 (4th Cir.), vacated and remanded, 2017 WL 4518553 (U.S. Oct. I0, 2017) (mem.) (per curiam).

296 Compare Zepeda v. INS, 753 F.2d 719,728 n.I (9th Cir. I983) (vacating national preliminary injunction because "[s]uch broad relief is not necessary to remedy the rights of the individual plaintiffs"), with Bresgal v. Brock, 843 F.2d I I63, I I 70-7 I (9th Cir. I 987) (affirming national injunction, and concluding that "an injunction is not necessarily made overbroad by extending benefit or protection to persons other than prevailing parties in the lawsuit - even if it is not a class action - if such breadth is necessary to give prevailing parties the relief to which they are entitled" (citing Gregory v. Litton Sys., Inc., 472 F. 2d 63 I, 633-34 (9th Cir. 1972))). For recognition that the same indeterminate principles are invoked for and against injunctions that control the defendant's conduct against nonparties, see Walker, supra note 6, at $\mathbf{I}_{\mathbf{1} 42}$.
} 
practice there is a bias toward broader relief. Moreover, the judge decides the scope of a permanent injunction only after finding that the defendant was liable. It is probably unavoidable that remedial decisions are made after liability decisions, but that fact again means that a judicial decision about complete relief is skewed toward a broader injunction.

Finally, the complete-relief principle hardens the remedial choices of equity, treating the equitable remedy as corresponding precisely to the underlying right. To the contrary, the scope of an equitable remedy is not at all automatic. There are a number of situations in which equitable remedies go beyond, or stop short of, the strict right of the plaintiff. ${ }^{297}$ Equity is concerned with justice not only for the plaintiff but also for the defendant. ${ }^{298}$ Complete relief is thus the starting point for equitable relief, but it is not and never has been the sole desideratum for the scope of equitable remedies. ${ }^{299}$

For these reasons it should be unsurprising that the complete-relief principle can coexist easily with national injunctions. It is not an effective limit. This is not to say it is a misguided idea. The complete-relief principle would be reasonable if it were treated as an equitable maxim. Like other maxims, it could focus judicial attention on an important aim or concern for equitable remedies. ${ }^{300}$ But a useful maxim is not the same thing as a limiting principle. Existing doctrine cannot solve the problem of the national injunction. ${ }^{301}$

297 See, e.g. Golden, supra note 27 (injunctions in patent law); David S. Schoenbrod, The Measure of an Injunction: A Principle to Replace Balancing the Equities and Tailoring the Remedy, $72 \mathrm{MINN}$. L. REV. 627 (I988) (injunctions generally); Tracy A. Thomas, The Prophylactic Remedy: Normative Principles and Definitional Parameters of Broad Injunctive Relief, 52 BUFF. L. REV. 301 (2004) (prophylactic injunctions); see also Truax v. Corrigan, 257 U.S. 31 2, 343 (I92 I) (Holmes, J., dissenting) ("[W]ithout legalizing the conduct complained of the extraordinary relief by injunction may be denied...."). Nevertheless, influential scholarship has treated injunctions as if they were effectively automatic in scope, being coextensive with the plaintiff's right. E.g., Guido Calabresi \& A. Douglas Melamed, Property Rules, Liability Rules, and Inalienability: One View of the Cathedral, 85 HARV. L. REV. 1089, I092, I I I6, I I I8, I I2 I (I972). But see Samuel L. Bray, Remedies, Meet Economics; Economics, Meet Remedies, OXFORD J. LEGAL STUD. (forthcoming) (criticizing the image of the injunction in One View of the Cathedral), https://ssrn.com/abstract=304I 7 I 9 [https://perma.cc/4QJR-QRGQ].

298 See Bush v. Gaffney, 84 S.W.2d 759, 764 (Tex. Civ. App. I 935).

299 See, for example, the discussion of equity's traditional emphasis on the defendant in Richard Hedlund, The Theological Foundations of Equity's Conscience, 4 OXFORD J.L. \& RELIGION II9, I24-26 (2015).

300 On this understanding of the equitable maxims, see Bray, supra note 140 , at 584-86. On the equitable maxims generally, see R.P. MEAGHER, W.M.C. GUMMOW \& J.R.F. LEHANE, EQUITY: DOCTRINES AND REMEDIES 7I-IOO (3d ed. I992); and Roger Young \& Stephen Spitz, Essay, SUEM - Spitz's Ultimate Equitable Maxim: In Equity, Good Guys Should Win and Bad Guys Should Lose, 55 S.C. L. REV. I 75 (2003).

301 When questioning the use of injunctions to benefit nonparties, Laycock has pointed to some cases that might be thought to limit the use of national injunctions. See LAYCOCK, supra note 6, at $275-76$. These limits are doubtful. It is true that in Horne v. Flores, for example, the Supreme Court urged the district court not to give a statewide injunction on remand but instead to give an 


\section{WHERE SHOULD WE GO FROM HERE?}

The status quo on national injunctions is not a very good translation of traditional equity. The injunction retains its potency, but without the institutional facts that made it intelligible to have such a concentration of powers in the hands of a single judge. These powers remain concentrated but are now duplicated (one judge has them, and another, and another, and so on). Moreover, older notions about challenges to invalid laws have lost force, and practices of restraint have broken down. Some compensating adjustments in the translation are needed. This Part proposes a solution, a rule for the scope of injunctions against federal defendants. This rule should be articulated by the federal courts, for the federal courts themselves should recognize the limits on their authority, instead of being required to do so by Congress. If the federal courts do not, however, the rule should be enacted by statute.

\section{A. Injunctions Should Be Plaintiff Protective}

Given that national injunctions are problematic, and that the existing doctrine is inadequate, what can be done? Let's begin with a simple rule: injunctions should not protect nonparties. Of course, in many cases involving federal law there will need to be some sort of injunction, so the simple rule can be specified a little further:

A federal court should give an injunction that protects the plaintiff visà-vis the defendant, wherever the plaintiff and the defendant may both happen to be. The injunction should not constrain the defendant's conduct visà-vis nonparties.

A rule of thumb for carrying this proposition into effect might be that an injunction should be no broader than what the plaintiffs - not in any kind of representative capacity, but solely for themselves should logically be able to bring contempt proceedings to enforce.

How would this work in practice? When a plaintiff sues to restrain the enforcement of a federal statute, regulation, or order, and wins, the national government will be unable to enforce the challenged law as to the plaintiff. Depending on the number of plaintiffs and their identity, the result might be broad but still partial nonenforcement.

\footnotetext{
injunction tailored to the plaintiffs. 557 U.S. $433,470-72$ (2009). Even so, the Court included an exception that may swallow the rule: "[T]he District Court should vacate the injunction insofar as it extends beyond Nogales unless the court concludes that Arizona is violating the [federal act in question] on a statewide basis." Id. at 472 (emphasis added). Another optimistic view of the current doctrine can be found in Josh Blackman \& Howard M. Wasserman, The Process of Marriage Equality, 43 HASTINGS CONST. L.Q. 243, 250 (2016), which sharply distinguishes injunctions and precedent, and asserts that only precedent affects nonparties. That assertion requires qualification, given the muddle of the existing cases. See supra section III.B, pp. $46 \mathrm{I}-62$.
} 
For example, in Texas $v$. United States there were twenty-six state plaintiffs. ${ }^{302}$ The states sued in their own capacity, alleging that they would suffer injuries such as financial costs from issuing drivers' licenses on the basis of the federal grant of lawful presence. ${ }^{303}$ A more sound injunction would have prohibited the federal government from enforcing its statutes and regulations so as to require the states to grant drivers' licenses on the basis of the federally granted lawful presence. Beyond their alleged injuries, the states had no basis for securing a remedy from the court. All other states - and even private parties within the geographic borders of the twenty-six plaintiff states - had no claim to an injunction against the Obama Administration's immigration policy.

Or consider the case of President Trump's initial executive order restricting entry to the United States by individuals from seven nations. ${ }^{304}$ For an individual litigant seeking entry to the United States, a successful challenge should bring an injunction forbidding the officers of the United States from denying him or her that entry. A federal court should not award that litigant a national injunction controlling the government's conduct toward those who are not parties before the court.

In Washington $v$. Trump, the plaintiffs who obtained the preliminary injunction were the states of Washington and Minnesota. ${ }^{305}$ Although the states alleged various kinds of injury, in denying a stay the Ninth Circuit relied on the states' strongest claim of irreparable injury, namely, their claim on behalf of students and faculty affiliated with their state universities who would be injured by denial of entry to and departure from the United States. ${ }^{306}$ That basis for the preliminary injunction points the way to its proper scope. ${ }^{307}$ The injunction should have restrained the federal government from enforcing the executive order against students and faculty affiliated with the state universities of Washington and Minnesota. ${ }^{308}$

30286 F. Supp. 3d 591, 604 (S.D. Tex.), aff'd, 809 F.3d I34 (5th Cir. 2015), aff'd by an equally divided Court, I36 S. Ct. 227 I (2016) (mem.).

303 Id. at 616-I7.

304 See supra p. 459.

305 See Washington v. Trump, 847 F.3d II 5 I, I I 57 (9th Cir. 20I 7 ) (per curiam).

306 Id. at I $168-69$.

307 The Ninth Circuit declined to reach the states' other arguments for standing. Id. at II6I n.5. Most of the alleged injuries are claims to parens patriae standing, which the Supreme Court rejected in Frothingham, 262 U.S. 447, 485-86 (1923). See generally RICHARD H. FALLON, JR., ET AL., HART AND WECHSLER'S THE FEDERAL COURTS AND THE FEDERAL SYSTEM $283-86$ ( 7 th ed. 2015) (discussing subsequent cases and qualifications).

308 Accord Aziz v. Trump, 234 F. Supp. 3d 724, 738-39 (E.D. Va. 201 7) (issuing a narrower injunction). The Ninth Circuit offered no affirmative argument for the national injunction, instead suggesting that the government had failed to show the legality of a "fragmented immigration policy," Washington v. Trump, 847 F.3d at I I66, and failed to propose "a workable alternative," id. at I I67. These are familiar but unpersuasive arguments for a national injunction. See infra sections V.B.2, 
In short, no matter whether the challenge is to the immigration policy of the Obama Administration or the Trump Administration, the courts should issue injunctions that protect the plaintiffs, not injunctions that protect nonparties.

To be sure, an injunction need not be a mere prohibition. An equitable remedy is flexible, and its scope is not automatic. The court can impose additional requirements on the defendant to ensure the plaintiff's rights are adequately protected, especially where the defendant has shown a propensity to disregard those rights. But there should be no term or breadth that is for the protection of nonparties rather than for the protection of the plaintiff.

The basis for the rule advanced here is twofold.

First, Article III of the Constitution of the United States confers the "judicial Power." 309 This is a power to decide a case for a particular claimant. Indeed, "all challenges to statutes arise when a particular litigant claims that a statute cannot be enforced against her." 310 This claimant-focused understanding of the judicial power has implications not only for who can sue in federal court, but also for what remedies the federal courts have authority to give. On this understanding, Article III defines the judicial role as "redress[ing] an injury resulting from a specific dispute." 311 Once a federal court has given an appropriate remedy to the plaintiffs, there is no longer any case or controversy left for the court to resolve. The parties have had their case or controversy resolved. There is no other. The court has no constitutional basis to decide disputes and issue remedies for those who are not parties. ${ }^{312}$

p. 476 , and V.B.4, pp. 478-79. On litigant arguments and the scope of an injunction, see supra note 140 and accompanying text.

309 U.S. CONST., art. III, § I ("The judicial Power of the United States, shall be vested in one supreme Court, and in such inferior Courts as the Congress may from time to time ordain and establish.").

310 Fallon, supra note I96, at I324; cf. Aaron-Andrew P. Bruhl, One Good Plaintiff Is Not Enough, 67 DUKE L.J. (forthcoming 2017) (critiquing the idea that standing needs to be established by only one of several plaintiffs), https://ssrn.com/abstract=2 901 I 22 [https://perma.cc/KL 72 -G8RJ].

311 Ariz. Christian Sch. Tuition Org. v. Winn, 563 U.S. I25, I32 (20II); see also Lewis v. Casey, 5 I 8 U.S. 343,349 (I996) ("It is the role of courts to provide relief to claimants, in individual or class actions, who have suffered, or will imminently suffer, actual harm; it is not the role of courts, but that of the political branches, to shape the institutions of government in such fashion as to comply with the laws and the Constitution."); Felix Frankfurter \& Henry M. Hart, Jr., The Business of the Supreme Court at October Term, 1934, 49 HARV. L. REV. 68, I03 (1935) (arguing that the Constitution made "the existence of a controversy between parties before the Court, and the necessity of resolving it, . . . the avowed and exclusive basis of the power of judicial review"). There are other understandings of Article III that emphasize judicial declaration of the law. See, e.g., Monaghan, supra note 203, at $1365-7$ I.

312 See City of Chicago v. Morales, 527 U.S. 41, 74 (rg99) (Scalia, J., dissenting) "The rationale for our power to review federal legislation for constitutionality . . . only extends so far as to require us to determine that the statute is unconstitutional as applied to this party, in the circumstances of this case."); Warth v. Seldin, 422 U.S. 490, 499 (I975) ("The Art. III judicial power exists only to redress or otherwise to protect against injury to the complaining party, even though the court's 
Nor can this conclusion be avoided by saying that the limits of Article.III control "standing" but not "remedies." In decision after decision, the Supreme Court has understood Article III as giving shape and definition to the remedial authority of the federal courts. ${ }^{313}$ Many of these cases have involved equitable remedies, with the Court insisting that the plaintiff show standing that is specifically correlated with the requested injunction. ${ }^{314}$ This intertwining of who can sue and what a court is willing to do on that person's behalf is supported by good reasons. Equitable remedies tend to be more costly and more vulnerable to abuse by the parties. ${ }^{315}$ They invite, and sometimes require, the court to manage the parties - and when one of those parties is, in effect, another branch of the national government or a state, concerns about separation of powers or federalism are heightened. ${ }^{316}$

In short, Article III gives the judiciary authority to resolve the disputes of the litigants, not the disputes of others. Article III gives the judiciary authority to remedy the wrongs done to those litigants, not the wrongs done to others.

judgment may benefit others collaterally."); Swann v. Charlotte-Mecklenburg Bd. of Educ., 318 F. Supp. 786, 793 (W.D.N.C. 1970) ("The orders of this court have been confined to the only area they can properly embrace, and that is the rights of the particular parties represented in this case, on the particular facts and history of this case."); see also Summers v. Earth Island Inst., 555 U.S. 488, 493 $(2009)$ (rejecting on Article III grounds the argument that "when a plaintiff has sued to challenge the lawfulness of certain action or threatened action but has settled that suit, he retains standing to challenge the basis for that action ... apart from any concrete application that threatens imminent harm to his interests").

313 See, e.g., Summers, 555 U.S. at 492-93; Lewis, 5 I 8 U.S. 343 ; City of Los Angeles v. Lyons, $46 \mathrm{I}$ U.S. 95 (I983); O'Shea v. Littleton, 4 I 4 U.S. 488 (I974); Aetna Life Ins. Co. v. Haworth, 300 U.S. 227 (1937); Liberty Warehouse Co. v. Grannis, 273 U.S. 70 (1927); Frothingham, 262 U.S. 447 (1923); Muskrat v. United States, 2 I 9 U.S. 346 (I 9 I I); $c f$. Tyson Foods, Inc. v. Bouaphakeo, I 36 S. Ct. 1036, I053 (20I6) (Roberts, C.J., concurring) ("Article III does not give federal courts the power to order relief to any uninjured plaintiff, class action or not.").

314 E.g., Summers, 555 U.S. at 493 ; Lewis, 518 U.S. at $357 ;$ Lyons, 46 I U.S. at 103-06, I I0, I I II3. There are many older examples intertwining what would now be called standing and the appropriateness of equitable relief. See, e.g., Mississippi v. Johnson, 7 I U.S. (4 Wall.) 475, 50I (I867) (" $[T]$ his court has no jurisdiction of a bill to enjoin the President in the performance of his official duties . . . "); Jacob Hoffman Brewing Co. v. McElligott, 259 F. 525, 53 I (2d Cir. 19I9) ("The right to maintain the suits, i.e., to give the injunctive relief prayed for . ..."). How exactly to characterize this connection between "standing" and "remedy" is not always clear. See FALLON ET AL., supra note 307 , at $232-34$.

315 See Bray, supra note 140 , at 572-78. On "equitable ripeness" as one of the equitable constraints, see $i d$. at $549 \&$ n.85.

316 In addition to these present, functional reasons for the likely remedy to inform standing, there is a reason grounded in history. At law, each of the forms of action was a bundle of what we would now call standing, merits, and remedies. Equity did not have the same sharply defined bundles. The equitable remedies could be complex, time consuming, and expensive, and there was only one Chancellor. Thus equity could not have a policy that once a plaintiff had passed some threshold of "standing," any equitable remedy, no matter how involved, would be available. Instead the Chancellor would look for ward to the remedy in considering "equitable jurisdiction," a concept that overlapped with what we would now call "standing" or "cause of action." 
A second basis is the Judiciary Act of $\mathrm{I} 789,{ }^{317}$ which has been interpreted as requiring the federal courts to trace their equitable doctrines to traditional equity. ${ }^{318}$ The rule advanced here can be supported by equitable principles, with the caveat that traditional equity needs to be translated for present-day institutions.

In the practice of traditional equity, injunctions did not control the defendant's behavior against nonparties. To that extent, the proposed rule carries over the traditional practice. Yet equity never condensed its practice into a sharply defined rule like the one advanced here. It never needed to. With only one Chancellor, and with a modest conception of what equitable relief was supposed to do, traditional equity did not need to develop rules to constrain the scope of injunctions. Indeed, even the equitable practices and principles that might seem to support national injunctions - such as the bill of peace ${ }^{319}$ and the extraterritorial force of equitable decrees ${ }^{320}$ - do not really do so once the facts of one Chancellor and equitable restraint are taken into account. This rule is a close translation of traditional equity into the present, with sensitivity to institutional and ideological changes. ${ }^{321}$

\section{B. Objections}

Against this rule at least five objections can be raised: one about differential treatment, two about complex regulatory systems, one about hard-to-detect plaintiffs, and one about the choice of a rule over a standard. Working through them will show the contours and the limits of the rule.

I. Differential Treatment. - The first objection is that the successful plaintiff will be treated differently from others. This objection can be

317 Ch. 20, I Stat. 73.

318 See Grupo Mexicano de Desarrollo, S.A. v. All. Bond Fund, Inc., 527 U.S. 308, 318-I9 (I999) (describing the equitable remedial authority of the federal courts as "an authority to administer in equity suits the principles of the system of judicial remedies which had been devised and was being administered by the English Court of Chancery at the time of the separation of the two countries," id. at 318 (quoting Atlas Life Ins. Co. v. W.I. Southern, Inc., 306 U.S. 563, 568 (I939))). For scholarship on traditional equity and the federal courts, see supra note 13.

319 See supra notes $36-45$ and accompanying text.

320 See Steele v. Bulova Watch Co., 344 U.S. 280,289 (I952) ("[T]he District Court in exercising its equity powers may command persons properly before it to cease or perform acts outside its territorial jurisdiction."); New Jersey v. City of New York, 283 U.S. 473, 482 (I93I) ("The situs of the acts creating the nuisance, whether within or without the United States, is of no importance. Plaintiff seeks a decree in personam to prevent them in the future."); Cole v. Cunningham, I33 U.S. ro7, I $16-2$ I (I 890) (reviewing English and American cases); Massie v. Watts, ro U.S. (6 Cranch) I 48, I58 (I $8 \mathrm{IO}$ ) ("[T] found ...."); 2 STORY, supra note $39, \$ 899$, at $230-32,230$ n.I, $\$ \S 1290-1300$, at $723-29$. For further discussion, see supra note i 9.

321 For further discussion of translating equity for the present, see Bray, supra note 26 . 
put in the language of treating like cases alike, or of equality, or of the rule of law. ${ }^{322}$ In each guise the point is the same.

One answer is that the differential treatment is grounded in differential actions. Because the plaintiff is the one who took the initiative and sued, it is the plaintiff who is protected. Others can receive the same protection if they take the same action by bringing their own suits (invoking the authority of the earlier decision). ${ }^{323}$

More generally, the evaluation should be made in light of the broader disuniformity in the law. In our system of courts - both federal and state, and with the federal courts divided among circuits - the choice has been made to allow some disuniformity. The only way to avoid it entirely is to have a single court for the United States. Failing that, the next closest thing would be to have lots of courts and allow whichever one took the case first to decide it for the nation. ${ }^{324}$ Once we are committed to seeking only eventual uniformity, then it is not a knock-out objection that the rule advanced here allows for disuniformity.

The question should be about the right moment to achieve uniformity - at what point should the uncertainty be liquidated, by what legal actor, and in what posture? With the question posed that way, it is impossible to think the best legal actor is a single district judge selected through forum shopping. Nor is the best posture a decision by the Supreme Court on a motion to stay the preliminary injunction issued by a district court selected thus. The better way to resolve the question is either through the unanimous alignment of lower courts or through disagreement among the lower courts followed by a series of decisions by the Supreme Court. In other words, the way to resolve legal questions for nonparties is through precedent, not through injunctions.

Precedent should be the ordinary way one case ripples out to others. ${ }^{325}$ What that means, in practical terms, is that a single plaintiff can win an injunction that protects her from the enforcement of a statute, regulation, or order. When the government appeals, if the appellate court affirms, its decision is a precedent within the circuit. There is no

322 See, e.g., Carroll, supra note 6, at 2033 ("When a court determines that the defendant's unlawful conduct is harming a large number of people, but orders the defendant to cease that conduct only as to one (or a handful) of them, allowing the violation to continue undermines the rule of law."); Morley, De Facto Class Actions?, supra note 6, at 490 (referring to "the unfairness that could result from enforcing certain plaintiffs' rights while allowing the challenged provision to otherwise remain in effect, violating the rights of others").

323 For this point and its pithy expression, I thank Douglas Laycock.

324 For a vivid cautionary tale, see Thomas O. McGarity, Multi-Party Forum Shopping for Appellate Reviere of Administrative Action, I29 U. PA. L. REV. 302, 320-22 (I980).

325 See generally RANDY J. KOZEL, SETTLED VERSUS RIGHT. A THEORY OF PRECEDENT (2017). 
need for dozens of other suits in the circuit; the law of the circuit can be settled promptly, and can then be applied to every new plaintiff. ${ }^{326}$

At this point, the depth and durability of the legal uncertainty depend on the actions of the national government, of other circuits, and of the Supreme Court. Current research suggests that when circuit splits emerge, they tend to emerge quickly. ${ }^{327}$ That is, when one circuit decides a question, if a circuit split is likely to emerge, it will emerge in the next one or two circuits to consider the question - not after half a dozen circuits have agreed about the resolution. If there is disagreement among the circuits, the likelihood is high that the Supreme Court will take the case and resolve the circuit split..328 In the meantime, each circuit's precedents apply only in that circuit. ${ }^{329}$

Such disagreement is not merely tolerable; it is good. The possibility that the federal government would apply a rule in some circuits but not others was blessed in United States $v$. Mendoza, ${ }^{330}$ the decision holding that nonmutual offensive issue preclusion does not apply against the United States. The Court said:

A rule allowing nonmutual collateral estoppel against the Government in such cases would substantially thwart the development of important questions of law by freezing the first final decision rendered on a particular legal issue. Allowing only one final adjudication would deprive this Court of the benefit it receives from permitting several courts of appeals to explore a difficult question before this Court grants certiorari. Indeed, if nonmutual estoppel were routinely applied against the Government, this Court would have to revise its practice of waiting for a conflict to develop before granting the Government's petitions for certiorari. ${ }^{331}$

Admittedly, there may be cases in which an injunction protecting only the plaintiff proves too narrow. But in such cases there is an obvious answer: a class action. Nothing about the analysis here precludes a Rule $23(\mathrm{~b})(2)$ class action (that is, a class action for injunctive or declaratory relief). Indeed, if federal courts were to end the practice of issuing national injunctions, and instead were to issue only plaintiff-protective

\footnotetext{
326 If the government does not appeal, the district court is likely to sustain as many challenges as are brought before it. The government may need to appeal somewhere, sooner rather than later, to stop the losses.

327 Deborah Beim \& Kelly Rader, Evolution of Conflict in the Courts of Appeals (Apr. 1, 2016) (unpublished manuscript), https://campuspress.yale.edu/beim/files/2016/og/Beim_Rader_Conflicts_ Princetonzor6-293mgzr.pdf [https://perma.cc/4T9G-SQJ2].

328 STEPHEN M. SHAPIRO ET AL., SUPREME COURT PRACTICE \$ 4.4, at 243-50 (roth ed. 2013).

329 E.g., Right to Life of Dutchess Cty., Inc. v. FEC, 6 F. Supp. 2 d 248, 252-53 (S.D.N.Y. I 998); see also Colby v. J.C. Penney Co., 8 I I F.2d I I I9, I I22-24 (7th Cir. I987). A possible further implication, if the trend toward state-initiated litigation continues, is that states could succeed in challenging national regulations even while those regulations remained enforceable in the District of Columbia, which would then be a site of experimentation for federal regulatory policy.

$330{ }_{4} 64$ U.S. I 54 (I 984 ).

331 Id. at 160 (citations omitted).
} 
injunctions, it would become easier to see the rationale for the Rule 23 (b)(2) class action as a means of achieving broad injunctive relief. ${ }^{332}$

It is true that the requirements for a class action will not always be easy to meet. For example, the interests of the potential class may vary. The class might need to be a narrower and more cohesive subgroup not everyone affected by the executive order restricting entry from seven countries, but all travel agents, for example. Yet the difficulty of fitting a case into the classic form of a class action is a reason to favor individual suits, not a reason to circumvent class requirements and jump straight to giving what is in effect class-wide relief.

In short, there is already ample disuniformity. It is intrinsic in having multiple federal courts, in having a federal system, and for that matter in having a large country. What changes, with the rule proposed here, is a shift in how (and how quickly) that disuniformity is resolved. It is resolved not through the single thunderbolt of a national injunction, but through the steady accumulation of precedent throughout the system of federal courts.

2. Regulatory Disruption. - A second objection is that a plaintiffprotective injunction, as opposed to a national injunction, would disrupt complex regulatory systems. Put more colloquially, regulation should not be piecemeal, but it would be piecemeal if the court gave one plaintiff a get-out-of-jail-free card. This point can be disposed of more quickly. Agencies are likely to prefer narrow injunctions to national injunctions. If the agency wants to respond to a narrower injunction by adopting the district court's resolution as a rule for the nation, it can do so. If the agency wants to keep its regulation, however, it can. If an appellate court affirms the ruling against the agency, thus setting circuit precedent, the agency can continue to enforce its rule in the other circuits. Again the scenario is not a nightmare: it was expressly contemplated and endorsed by United States v. Mendoza.

3. Regulatory Entrenchment. - The regulatory-disruption objection is about inconsistency at a particular moment. A stronger objection can be made about unwarranted consistency over time. Once a complex regulatory system goes into effect, the changes in behavior by administrative agencies and regulated entities may be effectively irreversible. Is an agency's bet on path dependence a reason to grant national injunctions?

This is perhaps the strongest case for a national injunction. ${ }^{333}$ There is no reason to respect an agency's preference for - even delight at the

\footnotetext{
332 For a discussion of the difficulty in justifying the Rule $23(\mathrm{~b})(2)$ class action if the same relief is available to an individual litigant, see supra note 279 and accompanying text. On the Rule 23 (b)(2) class action, see generally Carroll, supra note 6; and Marcus, supra note 222.

333 This case for national injunctions is strongest for preliminary injunctions, because they preserve the status quo in the sense of ensuring that the plaintiff is not irreparably injured before
} 
prospect of - losing individual battles, yet having already won the war because the policy change was irreversible. That agencies take this view is not hypothetical. ${ }^{334}$ Concern about this kind of path dependence may have driven the Supreme Court's highly unusual stay pending disposition in a challenge to the Obama Administration's Clean Power Plan. ${ }^{335}$ In short, to prevent individual litigants from winning only Pyrrhic victories, some kind of broad relief seems necessary before a regulatory scheme goes into effect:

The problem is real, but a national injunction is a crude solution. We cannot count on judicial willingness to give national injunctions to be a good filter for those regulations that are hardest or most costly to reverse. This is especially true given the forum shopping endemic to suits seeking national injunctions. And given the unfortunately moribund state of injunction bonds ${ }^{336}$ in federal courts, litigants have every reason to seek national preliminary injunctions against all regulatory initiatives, reversible or irreversible.

The better solution is legislative. Congress could enact a requirement that certain regulations be delayed for a period of time long enough to allow challenges to be brought and circuit precedent to be made. ${ }^{337}$ Or Congress could expressly require that "major rules" receive congressional approval ${ }^{338}$ or be subject to heightened procedures. ${ }^{339}$ Or, more

judgment and the court is not robbed of its ability to decide the case. See Univ. of Tex. v. Camenisch, 45 I U.S. 390, 395 ( 198 I); Centaur Co. v. Marshall, 97 F. 785, 786 (8th Cir. 1899) ("The purpose of a preliminary injunction is to prevent irremediable injury to some of the parties to the suit during its pendency, and before their claims can be investigated and adjudicated.").

334 After losing a case in the Supreme Court on its Mercury and Air Toxics Standards, the EPA described the Court's decision as having minimal effect because "the majority of power plants are already in compliance or well on their way to compliance." Janet McCabe, In Perspective: The Supreme Court's Mercury and Air Toxics Rule Decision, EPA BLOG (June 30, 20I5), https://blog.epa.gov/blog/2015/o6/in-perspective-the-supreme-courts-mercury-and-air-toxics-ruledecision/ [https://perma.cc/D9NK-CNBB].

335 See Chamber of Commerce v. EPA, I36 S. Ct. 999 (2016).

336 On injunction bonds and the supposed discretion that federal courts have not to require them, see generally I DOBBS, supra note $2 \mathrm{I}$, § 2.II(3), at 267-70; and LAYCOCK, supra note 6, at 453-56.

337 For one such proposal, see H.R. 5, I I5th Cong. (20I7). Title IV, entitled the "Require Evaluation Before Implementing Executive Wishlists Act," would require such a delay for regulations with an annual cost of over one billion dollars. Id. $\$ 402$.

338 See, e.g., H.R. 26, II5th Cong. (2OI7) (requiring congressional approval for certain regulations, including those with projected annual costs of over one hundred million dollars).

339 See, e.g., S. 95 I, 115 th Cong. (20I7); H.R. 5 tit. I, II 5 th Cong. ("Regulatory Accountability Act”). For further discussion, see Christopher J. Walker, Essay, Modernizing the Administrative Procedure Act, 69 ADMIN. L. REV. 629, 656-62 (2017), as well as the diverging evaluations in $A s-$ sessing the Regulatory Accountability Act, REG. REV. (May 30, 201 7), https://www.theregreview. org/2017/05/3o/assessing-regulatory-accountability-act/ [https://perma.cc/RDR6-7FZ6]. For judicial discussion of the "major questions" or "major rules" doctrine, which could be codified, see United States Telecom Association v. FCC, 855 F.3d 38I, 402-04 (D.C. Cir. 201 7 ) (en banc) (Brown, J., dissenting from the denial of rehearing en banc); and id. at 4I8-24 (Kavanaugh, J., dissenting from the denial of rehearing en banc). 
radically, Congress could push agencies toward making policy not primarily through rules but through adjudications, in accord with what seems to have been the design of the Administrative Procedure Act. ${ }^{340}$

4. Plaintiff Detection. - Another objection is that in some cases it would be impractical to have an injunction benefitting only the plaintiff, because it may be hard for the federal defendant to distinguish the plaintiff from other persons. The classic case on this question involves an injunction not against a federal agency but against the California Highway Patrol. ${ }^{341}$ The plaintiffs were "Easyriders Freedom F.I.G.H.T.," an unincorporated association of motorcyclists, and fourteen individual motorcyclists. The case involved the California Highway Patrol's aggressive enforcement of a state motorcycle helmet law, and in particular the stopping of motorcyclists who were not actually in violation of the helmet law (because the motorcyclists lacked subjective knowledge that their helmets were out of compliance with federal safety standards). ${ }^{342}$ The Ninth Circuit affirmed the holding that stopping the motorcyclists was a Fourth Amendment violation, and it also affirmed the injunction protecting all motorcyclists, not just the plaintiffs. ${ }^{343}$ Its analysis here has influenced a number of subsequent courts, and the key passage is worth quoting:

While there are only fourteen named plaintiffs in this case, spread among

San Diego, Orange, Los Angeles, and Ventura counties, and an unknown number of members of Easyriders, an injunction against the CHP [California Highway Patrol] statewide is appropriate. Because the CHP policy regarding helmets is formulated on a statewide level, other law enforcement agencies follow the CHP's policy, and it is unlikely that law enforcement officials who were not restricted by an injunction governing their treatment of all motorcyclists would inquire before citation into whether a motorcyclist was among the named plaintiffs or a member of Easyriders, the plaintiffs would not receive the complete relief to which they are entitled without statewide application of the injunction. ${ }^{344}$

Here the court advanced two reasons for the injunction protecting nonparties: the California Highway Patrol's policy was statewide, and officers did not know which motorcyclists on California roads were plaintiffs in the case (either individually or as members of Easyriders). The first reason has already been discussed above and should be rejected. ${ }^{345}$ The second is more interesting, and it has been noted uncrit-

\footnotetext{
340 See generally Schiller, supra note 121.

341 Easyriders Freedom F.I.G.H.T. v. Hannigan, 92 F.3d I486 (9th Cir. 1996).

342 See id. at I 492 .

343 Id. at $150 \mathrm{O} \rightarrow \mathrm{O} 2$.

344 Id. at 1502 .

345 See supra Part IV, pp. 465-68 (discussing complete-relief principle).
} 
ically by commentators, including some who are generally skeptical of national injunctions. ${ }^{346}$

Nevertheless, there are two good reasons not to make an exception in a case like Easyriders Freedom F.I.G.H.T. v. Hannigan, ${ }^{347}$ and instead to stick to the general rule that an injunction should protect only the plaintiffs.

First, an Easyriders exception allows for the circumvention of the general rule. If organizations with numerous members can get national injunctions, then a rule against national injunctions can be evaded with artful selection or construction of plaintiffs.

Second, the difficulty for the defendant is overstated. The key is that if the court gives a plaintiff-protective injunction, the burden is on the defendant to figure out how to comply. In the Easyriders case the court made this assumption: "[I]t is unlikely that law enforcement officials who were not restricted by an injunction governing their treatment of all motorcyclists would inquire before citation into whether a motorcyclist was among the named plaintiffs or a member of Easyriders." 348 But why is it unlikely? If the court issues an injunction protecting the plaintiffs, and stresses the certainty of contempt enforcement for any violations, why wouldn't the California Highway Patrol require officers to make exactly that inquiry? Or why couldn't the California Highway Patrol decide on a more creative option, such as distributing decals to the Easyriders? And if the California Highway Patrol makes the considered judgment that it would rather extend to all motorcyclists the protections in the court's injunction, why is that a problem? The court does not need to make the choice for the government defendant. ${ }^{349}$

5. A Standard, Not a Rule. - There are competing policy considerations in the choice between a plaintiff-protective injunction and a national injunction. On the one hand, a plaintiff-protective injunction has advantages with respect to forum shopping, percolation, and conflicting injunctions. On the other hand, there are policy concerns that in some circumstances favor a national injunction. These include concerns about the executive branch's continuing to enforce unconstitutional statutes and unlawful regulations, inequality in the administration of the law, and administrability.

\footnotetext{
346 See LAYCOCK, supra note 6, at 276; David Marcus, The Public Interest Class Action, I04 GEO. L.J. 777, 800-OI (2016).

34792 F.3d I486.

$348 I d$. at $\mathrm{I} 502$.

349 Accord Zepeda v. INS, 753 F.2d 7r9, 729 n.r (9th Cir. 1983) ("The individual plaintiffs need not take any action to identify themselves to make it easy for the INS to comply with the injunction. Rather, the burden is on the INS to comply ...."). Note that phasing in the injunction can allow the defendant time to work out a method for complying (where the defendant has not proved recalcitrant). If a plaintiff-protective injunction really is hopelessly impractical, that will sometimes be a reason not to give an injunction.
} 
These countervailing policy considerations seem to invite the use of a standard, not a rule. ${ }^{350} \mathrm{~A}$ standard would offer a middle ground between two opposite rules: a rule that says every injunction restraining the enforcement of a federal law should be a national injunction, and the rule proposed here (that is, no national injunctions). If we set aside the questions of positive law ${ }^{351}$ and coherence with other legal rules and practices, ${ }^{352}$ and merely ask a direct policy question, why is the proposal here a rule and not a standard?

The answer lies in the domain of the second best. Although in theory a standard would allow for the possibility of national injunctions in appropriate situations, ${ }^{353}$ in practice the use of a standard would be seriously deficient. The initial problem is that it seems inevitable that any standard for when national injunctions should issue would be highly indeterminate. Existing doctrine already contains such a standard: the complete-relief requirement. This standard should ideally offer a middle ground - national injunctions when necessary for complete relief, but no national injunctions when unnecessary for complete relief. But the middle position is not stable. Whenever a plaintiff challenges a federal statute, regulation, or order, the complete-relief principle allows the judge to award or not award a national injunction without any real limitations - it is almost wholly indeterminate. ${ }^{354}$ Other standards that might be proposed, such as the value of uniformity or the importance of the right, are also highly indeterminate. Remember, too, that any standard would also be applied to grants of preliminary injunctions, a point at which there has been no trial, with only a judicial surmise about the relevant policy considerations.

Related to the indeterminacy of a standard for injunctions are two further problems. First, the standard would be applied by a district judge selected through forum shopping. Second, that district judge's application of the standard would be reviewed only for abuse of discretion. Indeed, the forum shopping extends not only to the district court but also to the court of appeals. Thus, the problem with a standard can be stated starkly: a district court selected through forum shopping will apply a relatively indeterminate standard, which will then be leniently reviewed by a court of appeals also selected through forum shopping. (These arguments against a standard would also hold against a rebuttable presumption, either for or against a national injunction.)

\footnotetext{
350 I am grateful to Bob Bone for raising this objection.

351 That is, whether a proposed legal norm has a basis in existing constitutional law, statutory law, or judicial decisions. On the basis for the rule proposed here, see supra notes $2-9$ and accompanying text.

352 See supra section III.D, pp. $46_{4}-65$.

353 One example is the preliminary injunction in Youngstown. See supra note 96 and accompanying text.

354 See supra Part IV, pp. $465-68$.
} 
In short, the rule advanced here does not capture all of the competing policy considerations. But for the system of federal courts as it actually exists, this rule is an achievable second best. It is superior as a matter of policy to a standard such as complete relief.

\section{CONCLUSION}

The national injunction has a distortive effect on the decisionmaking of the federal courts and on the enactment and enforcement of law in the United States. A reader could have started with Part III and been convinced of this point, and then skipped to Part $\mathrm{V}$ and found the cure. If read that way, the Article has a pleasing sense of finality. The problem would appear isolated, an irrational irruption. It would be solved.

The complexity and depth of the problem come into view, however, once its historical and institutional aspects are recognized. The national injunction is a relatively new innovation, without any basis in traditional equity. What makes it problematic is a structural shift that happened when the federal courts were first established: the shift from the one-chancellor model of the English Chancery to the multiple-chancellor model of the federal courts.

For the federal courts, there is no going back to a one-chancellor model. Nor will the ideological changes that permitted the national injunction soon fade away. Yet it is valuable to understand where the national injunction came from, because having this understanding encourages us not to think that the solution is exhorting judges to behave better. This understanding also helps us think more carefully about the "traditional equity" that the federal courts look to when fashioning the principles of equity in the present. Traditional equitable doctrines were developed in a one-chancellor system. Equitable powers do not work the same way when the institutional setting changes dramatically; they cannot be carried over, all intact, to the present. A translation has to be made, and translation is a practice marked not only by fidelity but also by subtlety and creativity. ${ }^{355}$

It is possible, in a sense, to solve the problem of the national injunction. But the national injunction is intimately connected to another, deeper problem, namely, the speed at which legal questions are answered. Imagine that legal questions were resolved quickly, comprehensively, and with immediate finality. That system would be criticized as rash, perhaps even as an illegitimate exercise of authority. Imagine, by contrast, that legal questions were resolved slowly, piecemeal, and with a resolution that was only eventually final. That system would also be

355 See generally Bray, supra note 26 (considering ways of translating equity from the past to the present). 
open to criticism. For one person it might offer justice, but for others it might offer only justice delayed or outright denied.

This choice is a deep problem that will never be solved. ${ }^{356}$ Each legal system can pick its poison, tending toward the vices of immediate, final resolution or the vices of slow, provisional resolution. In this regard, there is a sharp contrast between the English Chancery and the federal courts. A medieval Chancellor spoke on behalf of God and King; an early modern Chancellor spoke on behalf of conscience and King. These claims of epistemic certainty and political authority fit hand-inermine-lined-glove with the existence of a single Chancellor. But the authority of federal judges is different. Power in the American political system is pervasively divided - through federalism, through the separation of powers, and through the sprawling system of federal courts. A legal question is resolved through patience and the consideration of many minds. Which system is better, if starting from scratch, is a difficult question. The question of which system obtains in the United States is easy to answer: a fragmented, many-minds system. In a system like ours, there is no room for the national injunction.

356 See EDWARD SHILS, TRADITION 323 (I981) ("There is no permanent solution to any important problem in human life. Only transient and minor problems have solutions ...."). 